\title{
SYMBOLIKA NÁMĚTU „ZVĚSTOVÁNÍ PANNĚ MARII“ V RÁMCI STRATEGIE UMĚLECKÉ SEBEREPREZENTACE NAZARÉNSKÝCH MALÍŘ U․ KONCEPCE FRANZE PFORRA, JOHANNA FRIEDRICHA OVERBECKA A JEJICH POKRAČOVATELŮ V ČECHÁCH: JOSEFA VOJTĚCHA HELLICHA A JOSEFA MÁNESA
}

\author{
JAN ŘEZÁČ \\ Absolvent doktorského studia na ÚDU FF UK, aktuálně soukromý badatel, Mnichov \\ E-mail: rezac@centrum.cz
}

\begin{abstract}
The symbolism of the theme of the Annunciation to the Virgin Mary in the selfpresentation strategies of the Nazarene painters. The concepts of Franz Pforr, J. F. Overbeck and their successors in Bohemia, J. V. Hellich and Josef Mánes
\end{abstract}

This study deals with one of the key subject of the iconography of Christian art, as treated in the same early 19th century by members of the Nazarene Brotherhood, and around the middle of the same century by two leading painters in Bohemia. The author refers to the period reflection of the history of the treatment of this subject. He examines the aspect of the above-listed artists' self-presentation in tackling the subject, in contexts ranging from the personal to the public.

Keywords: Annunciation Holy Mary; Josef Vojtěch Hellich; Josef Mánes; Nazarene painters; Johann Friedrich Overbeck; Franz Pforr; Julius Schnorr von Carolsfeld; Raffael

Cílem této studie ${ }^{1}$ je vymezení a popis prríčin obliby tématu Zvěstování Panně Marii u malířu sdružených od roku 1809 v neformálním spolku Svatolukášského bratrst$v a$, později známých pod zjednodušeným názvem nazaréni. ${ }^{2}$ Tento tradiční námět křestanské ikonografie se stal v jejich okruhu výrazným projevem sebeidentifikace současně umělecké a sociálně-psychologické, směřované částečně i vůči (tehdy poměrně úzké) skupině objednavatelů. Následné svědectví o přenesení tohoto „nazarénského“ konceptu (po rozpadu struktury původního společenství) do prostoru střední Evropy Prahy poloviny 19. století -, včetně rozvíjení nových významových poloh v prostředí změněných kontextů, je další publikovanou sondou v české odborné uměleckohistorické

1 Tento příspěvek vychází z mé magisterské práce vypracované a obhájené na Ústavu pro dějiny umění FF UK. Rešerše, týkající se vztahủ německého romantického umění k českým zemím, v Centrálním ústavu pro dějiny umění (Zentralinstitut für Kunstgeschichte) v Mnichově, podpořila na začátku nadace Leonhard Moll Stiftung. Zvláštní poděkování patří panu Siegfriedu Adamzigovi za jeho obětavou organizační činnost věnovanou stipendistům. Za přátelské konzultace a povzbuzení děkuji panu Stephanu Seeligerovi.

2 Srov. Michael Krapf, Zu den Voraussetzungen der Entstehung des Lukasbundes in Wien, in: Klaus Gallwitz (ed.), Die Nazarener in Rom. Ein deutscher Künstlerbund der Romantik (katalog výstavy), Galleria Nazionale d’Arte Moderna, Roma 1981, s. 27-33. Dále viz Jan Řezáč, Transformace forem a témat nazarénského maliŕstvív Čechách na příkladu oltáŕního obrazu Josefa Vojtěcha Hellicha (magisterská práce), Ústav pro dějiny umění, FF UK Praha 2009, s. 9-11 (Kapitola I.3. Pojmy Nazarénství, Nazaréni a nazarénské umění a jejich zasazení do historických souvislostí. 
literatuře, naznačující možná specifická, retrospektivní obohacení širšího proudu umění nazarénské orientace, vzešlá z českých zemí.

\section{Nazarénská sebereprezentace - strategie „vymezení se“}

Usilování o všeobecnou obnovu forem výtvarného umění (oproštěného od „umělectvi' $),{ }^{3}$ proklamované nazarény a doprovázené aspekty umělecké sebereprezentace, ${ }^{4}$ našlo faktické ztvárnění v promítání zážitků mladých umělců ${ }^{5}$ a jejich postupně nabývaném malířském vzdělání do nadreálné, transcendentální, Biblí a křest’anským náboženstvím definované, predestinované ikonografie, výtvarně zhmotněné mnohokrát v minulosti. ${ }^{6}$

Nosné tendence Svatolukášského bratrstva souvisí s dobovou vlnou odporu vưči sekularizaci a osvícenskému racionalismu. ${ }^{7}$ „Produchovnění, konkrétně vyjádřené sakralizováním individuálních prožitků ${ }^{8}$ a vzájemných sociálně-uměleckých vztahů, ${ }^{9}$ reflektuje život a na něj bezprostředně navazující umění prizmatem náboženství a náboženských

3 Např. Frank Büttner, Der Streit um die „Neudeutsche religiös-patriotische Kunst“, in: Aurora. Jahrbuch der Eichendorff-Gesellschaft XLIII, 1983, s. 55-76.

4 Pojem „sebereprezentace“ je zatím v uměleckohistorické literatuře spojován spíše s aktivitami donátorů a sociálním milieu, zejména v souvislosti s architekturou. Srov. Arnold Hauser, Soziologie der Kunst, München 1974, s. 317-320. - Edward B. Henning, Patronage and Style in the Arts: A Suggestion Concerning Their Relations, in: Milton C. Albrecht - James H. Barnett-Mason Griff (edd.), The Sociology of Art and Literature, New York 1976, s. 359-361. - Manfred Jauslin, Die gescheiterte Kulturrevolution. Perspektiven religiös-romantischer Kunstbewegung vor der Folie der Avantgarde (disertační práce), Universität Basel 1988, s. 22-25, 65-67. - Paul Guyer, Exemplary Originality: Genius, Universality, and Individuality, in: Berys Gaut - Paisley Livingston (edd.), The Creation of Art. New Essays in Philosophical Aesthetics, Cambridge 2003, s. 116-118. „Sebereprezentaci“ nazarénů (tak, jak ji zde interpretuji) je potřeba chápat především vzhledem k okruhu potenciálních divákủ, jenž byl zpočátku omezen.

5 Průměrný věk členů Svatolukášského bratrstva v době jeho založení se pohyboval kolem dvaceti let (kromě Josepha Suttera).

6 Srov. Alfred Neumeyer, Die Erweckung der Gotik in der deutschen Kunst des späten 18. Jahrhunderts. Ein Beitrag zur Vorgeschichte der Romantik (disertační práce), Friedrich-Wilhelms-Universität zu Berlin 1928, s. 5-7, 61-63, 66-70, 72-74. - Harald Keller, Goethes Hymnus auf das Straßburger Münster und die Wiederentdeckung der Gotik im 18. Jahrhundert. 1772/1972, München 1972. - Paul Eich, Über das Verhältnis der Nazarener zum Mittelalter, in: Klaus Gallwitz (ed.), Die Nazarener (katalog výstavy), Städtische Galerie im Städelschen Kunstinstitut Frankfurt am Main 1977, s. 27-40. - Hannelore Gärtner, Patriotismus und Gotikrezeption der deutschen Frühromantik, in: Peter Betthausen (ed.), Studien zur deutschen Kunst und Architektur um 1800, Dresden 1981, s. 34-52. - Nejnověji napr. Sabine Fastert, Die Entdeckung des Mittelalters, München - Berlin 2000, s. 231-237, 251-255.

7 K sekularizačním tendencím na začátku 19. století synteticky: Berthold Hinz, Säkularisation als verwerteter „Bildersturm“. Zum Prozeß der Aneignung der Kunst durch die bürgerliche Gesellschaft, in: Martin Warnke (ed.), Bildersturm. Die Zerstörung des Kunstwerks, München 1973, s. 108-120, 170-176. - Renate Liebenwein-Krämer, Säkularisierung und Sakralisierung. Studien zum Bedeutungwandel christlicher Bildformen in der Kunst des 19. Jahrhunderts (disertační práce), Johann Wolfgang Goethe Universität zu Frankfurt am Main 1977.

8 Srovnání poskytují např. slova nejstaršího člena Svatolukášského bratrstva Josepha Suttera, publikovaná in: Ludwig Grote, Joseph Sutter und der nazarenische Gedanke, München 1972, s. 57.

9 Vztah umělcủ k dobové společnosti vedl až k ideji autonomního „uměleckého státu“/,státu umělcu“. Srov. Michael Thimann, Der ,glücklichste kleine Freystaat von der Welt"? Friedrich Overbeck und die Nazarener in Rom, in: Ulrich Raulff (ed.), Vom Künstlerstaat. Ästhetische und politische Utopien, München - Wien 2006, s. 61, 74-76, 81-82, 96. 
koncepcí. ${ }^{10}$ Ty jsou obohaceny (zdánlivě „protiromantickými“) prvky etablování se do širší společnosti, do rodinných pocitů i sublimní erotiky, ${ }^{11}$ navíc jsou kombinovány s ještě dětsky „naivně“ hravým pohledem na svět a jeho zákonitostmi. ${ }^{12}$

Výsledkem tohoto snažení jsou figurální kompozice, které mají legitimovat obnovené ideové a také formální standardy umění, jak o tom svědčí dvě kresby Franze Pforra ${ }^{13}$ Raffael, Fra Angelico (Fiesole) a Michelangelo, zjevující se na oblaku nad Římem ${ }^{14}$ [Obr. 1] a Albrecht Dürer a Raffael, klečicí v adorační modlitbě před personifikovaným trůnícím Umèním. ${ }^{15}$ [Obr. 2] Druhá z těchto kreseb je inspirována typem benátské Sacra conversazione a ikonografií Sposalizio ${ }^{16}$ (kombinováním maleb z okruhu Giovanni Belliniho a Pintoricchia), ${ }^{17}$ využívá ale i prvků sochařství jihoněmecké pozdní gotiky (figura

10 Tato tématika je v současné uměleckohistorické literatuře postupně rozpracovávána mj. jako doplnění studie Hanse Sedlmayra, Verlust der Mitte. Die bildende Kunst des 19. und 20. Jahrhunderts als Symptom und Symbol der Zeit, Salzburg 1965, s. 168-172, 173-179. - Dále rovněž: Werner Hofmann, Das Irdische Paradies. Motive und Ideen des 19. Jahrhunderts, München 1974, s. 55-56.

11 Srov. s programovým textem malíře Franze Pforra, publikovaným in: Steffan Matter - Maria-Christina Boerner, ...kann ich vielleicht nur dichtend mahlen? Franz Pforrs Fragment eines Künstlerromans und das Verhältnis von Poesie und Malerei bei den Nazarenern, Köln - Weimar - Wien 2007, s. 17-19. - Srov. podobné inspirující vizionářsko-eufemistické verše básníka Friedricha von Hardenberga (Novalise): např. Novalis, Hymny k poctě noci, Praha 2000, s. 22.

12 Srov. s výtvarnými artikulacemi v tomto smyslu: Franz Pforr, Vjezd císaře Rudolfa Habsburského do Basileje v roce 1273, 1808-1810, olej, plátno, 90,5 x 118,9 cm, neznačeno, Städelsches Kunstinstitut, Frankfurt am Main, inv. č. HM 51; Franz Pforr, Hrabě Rudolf Habsburský nabízi knězi svého koně, 1809-1810, olej, plátno, 45,5 ×54,5 cm, neznačeno, Städelsches Kunstinstitut, Frankfurt am Main, inv. č. 951. Tyto obrazy popsal Fritz Herbert Lehr, Die Blütezeit romantischer Bildkunst. Franz Pforr der Meister des Lukasbundes, Marburg an der Lahn 1924, s. 124. Ćástečnou analýzu poskytuje Kurt Löcher, Zu Franz Pforrs „Einzug Kaiser Rudolfs von Habsburg in Basel“ - Vom Nutzen Wiener Studienjahre, in: Bruno Klein - Harald Wolter-von dem Knesebeck (edd.), Nobilis arte manus. Festschrift zum 70. Geburtstag von Antje Middeldorf Kosegarten, Dresden - Kassel 2002, s. 428-440. „Dětsky naivní “ stylizace obsažená ve formě díla je trvalým základem tvorby německé romantiky. Srov. Eckart Kleßmann, Die deutsche Romantik, Köln am Rhein 1979, s. 81.

13 Ideovou vůdčí roli Franze Pforra v počátcích Svatolukášského bratrstva zdůraznil již Paul F. Schmidt, Die Lukasbrüder. Der Overbecksche Kreis und seine Erneuerung der religiösen Malerei, Berlin 1924, s. 10.

14 Franz Pforr, Raffael, Fra Angelico (Fiesole) a Michelangelo, zjevující se na oblaku nad Římem, 1810, tužka, papír, 301 × 208 mm, neznačeno, Städelsches Kunstinstitut, Frankfurt am Main, inv. č. 6.

15 Franz Pforr, Albrecht Dürer a Raffael, klečicí v adorační modlitbě před personifikovaným trünícím Uměním, kolem 1810, technika a rozměry nezjištěny, nezvěstné (původně v majetku paní Schöff-Thomas, Frankfurt am Main). Tato kresba je známa pouze v podobě grafického přepracování Carlem Hoffem ml. (1807-1862), které vzniklo na objednávku Kunstvereinu ve Frankfurtu nad Mohanem: Carl Hoff ml. (před 1832, rytina, papír, $137 \times 214 \mathrm{~mm}$, neznačeno).

16 K pojmu Sacra conversazione nejlépe: Heidrun Stein-Kecks, „Santa (sacra) Conversazione“. Viele Bilder, ein Begriff und keine Definition, in: Karl Möseneder - Gosbert Schüssler (edd.), „Bedeutung in den Bildern". Festschrift für Jörg Traeger zum 60. Geburtstag, Regensburg 2002, s. 413-442. - K ikonografii „Zasnoubení Panny Marie“ (Sposalizio): Paul Wilhelm von Keppler, Aus Kunst und Leben, Freiburg im Breisgau 1911, s. 277-292. - Teresa Grzybkowska, Overbecka interpretacja Sposalizio Rafaela, in: Marta i Wojciech Boberscy - Mieczyslav Morka - Hanna Samsonowicz (ed.), Miêdzy Padwa a Zamoceiem. Studia $z$ historii sztuki i kultury nowozytnej ofiarowane profesorowi Jerzemu Kowalczykowi, Warszawa 1993, s. 372-373. - Tom Henry, I committenti di Raffaello a Città di Castello (Raphael's patrons in Città di Castello), in: Tom Henry - Francesco Federico Mancini (edd.), Gli esordi di Raffaello tra Urbina, Città di Castello e Perugia (katalog výstavy), Palazzo Vitelli alla Cannoniera, Pinacoteca Comunale, Città di Castello - Perugia 2006, s. 49-54.

17 Pietro Scarpellini - Maria Rita Silvestrelli, Pintoricchio, Milano 2004, s. 181-187. - Francesco Buranelli, Lappartamento Borgia in Vaticano, in: Vittoria Garibaldi - Francesco Federico Mancini (edd.), Pintoricchio (katalog výstavy), Galleria Nazionale dell'Umbria 2008, s. 69-70. Pintoricchiova kompozice - freska, zdobící prostor vatikánského L’appartamento Borgia, je prííkladem sekularizace 
Albrechta Dürera). Naopak ideové zázemí této výtvarné syntézy tvoří texty Georga Wolfganga Knorra a Wilhelma Heinricha Wackenrodera. ${ }^{18}$ Tyto Pforrovy kompozice tak transformují tradiční zobrazení náboženského námětu, event. formu oltářního obrazu, v programovou alegorii a prezentují intence Svatolukášského spolku pomocí bipolární, resp. tripolární skupinové, nadčasové podobizny obdivovaných tvůrčích vzorů.

Koncepce obou kreseb - „povýšeni“ Umění včetně jeho revokovaných záměrů do nadpozemské roviny (u výjevu Raffael, Fra Angelico a Michelangelo, zjevující se na oblaku nad Římem obohacené o moment „zbožštění“ umělců ${ }^{19} \mathrm{v}$ návaznosti na výtvarné rozvržení apoteóz, event. glorií pozdní gotiky a severské renesance ${ }^{20}$ ) - je zároveň systémovým vyjádřením různých př́ístupů k možnostem vizuálního zobrazení a jeho působení na diváka: cesty př́rody tzn. napodobení (Dürer, Fra Angelico), fantazie (Michelangelo) a krásy - ideálu (Raffael). ${ }^{21}$

Druhá ze zmiňovaných Pforrových kompozic klade navíc důraz na složitější modelování dějové situace - okolnosti, za jakých umělci před trůnem zhmotněného, alegorizovaného Umění (v modlitbě) klečí, a tím jej zároveň adorují22 jako ochranné, patronátní božstvo, „Vyšší “ ideu i sakralizovanou inspirující múzu. ${ }^{23}$ Kresbu charakterizuje navíc poloha zdůraznění protichůdných uměleckých kvalit obou zobrazených aktérů (Dürera a Raffaela), vyjádřená traktováním jejich figur, postoji, oblečením a rozdílnými místy v pozadí, „transparentem“, který však zpodobení historičtí malíři zároveň společně ideově zastupují a reprezentují ve smyslu výběrové syntézy. ${ }^{24}$ Koncept, zamýšlený jako výraz př́tomnosti obou hlavních představitelů Svatolukášského bratrstva, je prostředkovaný

náboženského námětu v renesančním umění. Alegorie Svobodných umění (Artes liberales) vychází $\mathrm{v}$ tomto př́padě z tradičního typu Sacra conversazione. K Pforrovu studiu Pintoricchiových římských obrazů viz: Lehr (pozn. 12), s. 279. - Jörg Traeger, Renaissance und Religion. Die Kunst des Glaubens im Zeitalter Raphaels, München 1997, s. 430-433.

18 Wilhelm Heinrich Wackenroder - Ludwig Tieck, Herzensergießungen eines kunstliebenden Klosterbruders, Stuttgart 1987, s. 58-59. Wackenroder při práci na tomto svém spise patrně vycházel mj. také z biografí́ umělců od Giorgia Vasariho a Lodovica Dolce.

19 Renesanční označení geniálního umělce jako divinus je v tomto smyslu třeba zaměnit za přiléhavější termín sanctus. Srov. Liebenwein-Krämer (pozn. 7), s. 236.

20 K tomu srov. Martin Sonnabend, Franz Pforr in Rom, in: Margreth Stuffmann - Werner Busch (edd.), Zeichnen in Rom 1790-1830, Köln am Rhein 2001, s. 48. - Mareike Henning, Mit freier Hand. Deutsche Zeichnungen vom Barock bis zur Romantik aus dem Städelschen Kunstinstitut (katalog výstavy), Städelsches Kunstinstitut und Städtische Galerie Frankfurt am Main 2003, s. 179-181.

21 Toto vymezení uvádí Johann Friedrich Overbeck ve svém textu Drei Wege der Kunst. Viz Brigitte Heise, Johann Friedrich Overbeck. Das künstlerische Werk und seine literarischen und autobiographischen Quellen, Köln - Weimar - Wien 1999, s. 108-111, 296-299. Overbeckův text se zachoval v písemné pozůstalosti Franze Pforra.

22 Srovnání poskytuje podobné duální vyrovnávání se Giotta s uměním Cimabuea v Dante Alighieriho Divina commedia. Srov. Ernst H. Gombrich - Ernst Kris - Otto Kurz, Die Legende vom Künstler, Frankfurt am Main 1980, s. 46-48. V souvislostech s Platónovou a Aristotelovou, resp. Plotinovou teorií ideální (krásné) formy, vzešlé z „duše-myšlenky svého tvůrce“, např. Erwin Panofsky, Idea. Ein Beitrag zur Begriffgeschichte der älteren Kunsttheorie, Berlin 1960, s. 12-16.

23 Johann Friedrich Overbeck ji později promítnul (př́mo) do postavy Panny Marie. Srov. Franz Binder (ed.), [Margaret Howitt], Friedrich Overbeck. Sein Leben und Schaffen. Nach seinen Briefen und andern Documenten des handschriftlichen Nachlasses geschildert von Margaret Howitt. Zweiter Band: 1833-1869, Freiburg im Breisgau 1886, s. 62. V souvislostech s neoplatónskou naukou, propagovanou v renesanční Florencii Marsiliem Ficinem, pojednáno např. Raymond Klibansky - Erwin Panofsky Fritzl Saxl, Saturn und Melancholie, Frankfurt am Main 1990, s. 370-371.

Klaus Lankheit, Freundschaftsbild der Romantik, Heidelberg 1952, s. 138. 
splynutím, ztotožněním se s jejich vzory - Franz Pforr jako Albrecht Dürer a Johann Friedrich Overbeck jako Raffael. ${ }^{25}$

V rané (sebeidentifikační) fázi své tvorby setrvávají tak nazarénští umělci ponejvíce v mezích intimního rámce svého kruhu - úzké elitní skupiny, která vedla programově výtvarně vyjadřovanou, subtilní, sofistikovanou, vzájemně obohacující kreativní komunikaci, pointovanou často připojením vlastních autoportrétů a portrétů. ${ }^{26}$

Umění nazarénů se zároveň od samého počátku pohybovalo mezi prosazováním vlastních tvůrčích postupů a napodobením (srov. s kontrastně pojímanými pojmy Johanna Davida Passavanta Nachahmung a Nachbildung). Tento zdánlivý paradox je úzce spjat se situací vyrovnávání se (vyvíjejícího se) uměleckého individua s potenciálními vzory. Je zastřešen ideou podřízení se Bohu, tzn. vymezením se jednotlivých členů Svatolukášského bratrstva a celku tohoto postupně se rozšiřujícího uměleckého společenství jako „božích služebníků“, mj. právě za pomoci též pro tento účel uměle konstruovaných strategií pozdně gotických a renesančních umělců (především Raffaela), ${ }^{27}$ ztotožňovaných navíc mnohdy s křestanskými světci i samotným Ježíšem Kristem. ${ }^{28}$

Z toho pramenící významovou mnohoznačnost nazarénského umění - složité obsahy, kterým nelze zcela porozumět bez textových výkladů jednotlivých tvůrců, a systém přejímání historických forem, na něž nazarénské kompozice navazují, doplňuje výsledný efekt, který zahrnuje kromě faktoru rozvíjení fantazie potenciálního diváka také morální a etické apely. ${ }^{29}$ Konečný výsledek je v tomto smyslu potřeba vnímat jako produkt osvícenstvím podníceného didaktického usilování, výchovy v „náboženském“, svébytně křestanském smyslu, jak bylo, nezávisle na nazarénech, ustaveno a definováno mj. romantickými tezemi bratř́i Friedricha a Augusta Wilhelma Schlegelových. ${ }^{30}$

25 Franz Pforr byl nazarény oslovován jako Albrecht Mainstädter (aluze na Albrechta Dürera a zároveň na Pforrův původ z Frankfurtu nad Mohanem), Johann Friedrich Overbeck jako Johannes (první Overbeckovo jméno a také ztotožnění se sv. Janem Evangelistou). Teprve po Pforrově smrti byl nově přijatý člen Svatolukášského bratrstva Johann Evangelist Scheffer von Leonhardshoff označován jako Raffaellino. Rudolf Preimesberger, Einleitung, in: Rudolf Preimesberger - Hannah Baader - Nicola Suthor (edd.), Porträt, Berlin 1999, s. 50. - Heise (pozn. 21), s. 85.

26 Srov. napr. Roland Kanz, Die Einheit des Charakters. Die Seelenhafte, Symbolische und Charakteristische in der Porträt - Ästhetik der Romantik, Zeitschrift für Ästhetik und allgemeine Kunstwissenschaft XLIII, 1998, č. 2, s. 229-243; Cordula Grewe, Objektivierte Subjektivität: Identitätsfindung und religiöse Kommunikation im nazarenischen Kunstwerk, in: Max Hollein - Christa Steinle (edd.), Religion Macht Kunst. Die Nazarener (kat. výst.), Schirn Kunsthalle Frankfurt am Main 2005, s. 79-90. - Rezáč (pozn. 1), s. 28.

27 K tomu mj. monografická studie: Elisabeth Schröter, Raffael-Kult und Raffael-Forschung. Johann David Passavant und seine Raffael-Monographie im Kontext der Kunst und Kunstgeschichte seiner Zeit, in: Römisches Jahrbuch der Bibliotheca Hertziana XXVI, 1990, s. 309-318.

28 Srov. Cordula Grewe, Re-enchantment as Artistic Practise: Strategies of Emulation in German Romantic Art and Theory, in: New German critique XCIV, 2005, s. 58.

29 Např. Matter - Boerner (pozn. 11), s. 203.

30 Vycházím z analytických textů: Emil Sulger Gebing, A. W. und F. Schlegel in ihrem Verhältnisse zur bildenden Kunst, in: Franz Muncker (ed.), Forschungen zur neueren Literaturgeschichte. Band III, Hildesheim 1976, s. 147-148. - Ellen Spickernagel, „Das Innerste erschüttern und bewegen“. Zur religiösen Tafelmalerei der Nazarener, in: Klaus Gallwitz (ed.), Die Nazarener (katalog výstavy), Städtische Galerie im Städelschen Kunstinstitut Frankfurt am Main 1977, s. 117. 


\section{Náboženská alegorie - výtvarný výraz nazarénské sebereprezentace}

Specifičnost tematického ohraničení vznikajícího nazarénského umění spočívá především v typu náboženské alegorie. ${ }^{31}$ Náboženská alegorie přesahuje tradiční druhové dělení malířství a obsahuje ikonografické spojení Bible, legend svatých atp. s literárními předlohami a autobiografickými texty nazarénů. Navazuje tak na středověký komplexní ideál, který spojoval sakrální umění s tvưrcovým bezprostředním životem - jeho smyslovým vnímáním. ${ }^{32} \mathrm{~V}$ tomto kontextu vychází částečně z kompozičních předloh devočního obrazu (Andachtsbild). ${ }^{33}$

Vytvoření a obliba náboženské alegorie v počátcích tvorby Friedricha Overbecka a především Franze Pforra, předtím, než se nazarénské umění etablovalo v širších společenských souvislostech na monumentálních projektech, jsou důsledkem obsahových změn v umění ${ }^{34}$ stimulovaných dobovými proměnami sociálního prostředí na začátku 19. století. Tyto tendence připravily půdu pro tvorbu, v níž je kombinována křestanská ikonografie s glorifikací „žánrového“ privátního společenství, ideálního a sakralizovaného rodinného kruhu, event. touhy po něm, ${ }^{35}$ již se zárodky záměru oslovit tímto způsobem co možná nejširší divácké spektrum. ${ }^{36}$

Takto transformovaná alegorie je v nazarénském podání veskrze romanticky poetická a postavy, resp. figury v ní jsou posouvány časem a prostorem, kombinováním „reálných“ a „transcendentálních“ těl, ${ }^{37}$ pozemského s nadpozemským, viditelného s neviditelným. ${ }^{38}$

31 Georg Jäger, Das Gattungsproblem in der Ästhetik und Poetik von 1780 bis 1850, in: Jost Hermand - Manfred Windfuhr (edd.), Zur Literatur der Restaurationsepoche 1815-1848, Stuttgart 1970, s. 371-404. - Jan Řezáč, Evropský kontext k ztvárněni figury v českém malírství druhé třetiny 19. století. Ideové a formální zázemí tvorby Josefa Mánesa (disertační práce), Ústav pro dějiny umění FF UK, Univerzita Karlova v Praze, Praha 2015 s. 41-42.

32 Heise (pozn. 21), s. 84-85. Werner Busch pracuje se širším pojmem romantická alegorie (Romantische Allegorie). Werner Busch pracuje se širším pojmem romantická alegorie (Romantische Allegorie). Werner Busch, Die notwendige Arabeske. Wirklichkeitsaneignung und Stilisierung in der deutschen Kunst des 19. Jahrhundert, Berlin 1985, s. 39, 42-43.

33 Karl Schade, Andachtsbild. Die Geschichte eines kunsthistorischen Begriffs, Weimar 1996, s. 25-29; Cornelia Reiter, Suche nach dem Unendlichen. Aquarelle und Zeichnungen der deutschen und österreichischen Romantik aus dem Kupferstichkabinett der Akademie der bildenden Künste Wien, München London - New York 2001, s. 53. Viz také pozn. 85.

34 Srov. Herbert Schindler, Nazarener. Romantischer Geist und christliche Kunst im 19. Jahrhundert, Regensburg 1982, s. 77.

$35 \mathrm{~V}$ tomto smyslu pracují němečtí badatelé s druhovým pojmem (těžko převeditelným do české uměleckohistorické terminologie) Freundschaftbild jako alegorickým ztvárněním přátelství. Lankheit (pozn. 24). - Téma koncízně sumarizované např. v Reinhard Teske, Studien zur Genremalerei im Vormärz (disertační práce), Universität Stuttgart 1976, s. 148-155.

36 Např. Herbert von Einem, Deutsche Malerei des Klassizismus und der Romantik. 1760-1840, München 1978, s. 107. - Christian Scholl, Romantische Malerei als neue Sinnbildkunst. Studien zur Bedeutungsgebung bei Philipp Otto Runge, Caspar David Friedrich und den Nazarenern, München - Berlin 2007, s. 184. - Busch (pozn. 32), s. 236.

37 Srov. s kapitolou IX.b. Figura a její význam - figura transcendentalizovaná a transcendentální v Řezáč (pozn. 31), s. 120-125.

38 Hans Joachim Ziemke, Die Anfänge in Wien und in Rom, in: Klaus Gallwitz (ed.), Die Nazarener (kat. výst.), Städtische Galerie im Städelschen Kunstinstitut Frankfurt am Main 1977, s. 46. Toto „nejasné “ vymezení obsahů v obrazové kompozici považuje Ziemke za obecně „romantické. Ke srovnání charakteristika pojmu „romantický" od Clemense Brentana (román Godwi). - Clemens Brentano, Ausgewählte Werke. Bd. II, München 1963, s. 258. - K „poetické" poloze srov. napr. Hans Geller, Ernste 
Ve své subtilní podobě později postupně vplývá do druhu malírství, označovaného nejčastěji jako historická malba či historický obraz (Historienmalerei/Historienbild). ${ }^{39}$

\section{Programové texty nazarénů a ikonografie „Zvěstování Panně Marii"}

Hledané a nově tvořené výtvarné formy byly v rámci strategií Svatolukášského bratrstva doplněny koncepty literárními, ${ }^{40}$ jež sice dokládají nezralost svých tvưrců v tomto oboru, pečlivě ale dokumentují jejich vzájemný podíl při komponování svébytné ikonografie a rekonceptualizující (prostřednictvím umění) významy širších společenských snah a dějů ${ }^{41}$ charakterizovaných sekularizací a následnou sakralizací - prolínáním náboženského s profánním. ${ }^{42}$

Beletristické a básnické pokusy objasňující jejich tvưrčí, fantazijní procesy (jejichž pomocí chtěli nazaréni především poznat, popsat a prohloubit své citové vnímání) nejsou jenom interpretací samotného, nezávisle na textu traktovaného výtvarného díla, ${ }^{43}$ nýbrž též svébytnou, esteticky autonomní složkou. Její substance vznikala v úzké souvislosti s dobovou romantickou literaturou „středověkého“ ražení. Stala se zároveň specifickým „žánrem“, součástí nazarénské prezentace prostřednictvím textu - sebereprezentace vyjádřené psaným slovem.

Důraz kladený na literární text nebo alespoň náčrt textového doprovodu k vizuálnímu zobrazení (i jednotlivé kresebné návrhy a studie byly nazarény na rubové straně popsány ${ }^{44}$ dokládají i následující citované pasáže, věnované ikonografii „Zvěstování Panně

Künstler, fröhliche Menschen. Zeichnungen und Aufzeichnungen deutscher Künstler in Rom zu Beginn des 19. Jahrhunderts. Joseph Führich und seine Freunde, München 1947, s. 167, 170.

39 Srov. Busch (pozn. 32), s. 86. - Oskar Bätschmann, Das Historienbild als „tableau“ des Konflikts: Jacques-Louis Davids „Brutus“ von 1789, Wiener Jahrbuch für Kunstgeschichte XXXIX, 1986, s. 156-159. - Helmut Börsch-Supan, Die Deutsche Malerei von Anton Graff bis Hans von Marées. 1760-1870, München 1988, s. 274. - Joachim Großmann, Historienmalerei im 19. Jahrhundert Entstehungsbedingungen und Rezeption, Kritische Berichte. Zeitschrift für Kunst und Kulturwissenschaften XX, 1992, č. 2, s. 24-35. - Frank Büttner, Aufstieg und Fall der Geschichtsmalerei. Ein Überblick über die Entwicklung von Gattungsgeschichte und Gattungstheorie in Deutschland vom späten 18. bis zum frühen 20. Jahrhundert, in: Ulrich Baumgärtner - Monika Fenn (edd.), Geschichte zwischen Kunst und Politik, Münchner Geschichtsdidaktisches Kolloquium, Heft 4, München 2002, s. 36-38. Do kategorie malírủ zabývajících se historickou malbou byli většinou počítáni také tvưrci oltářních obrazů.

40 Historický a metodologický průřez touto tématikou: Ulrich Weisstein, Einleitung, Literatur und bildende Kunst: Geschichte, Systematik, Methoden, in: Idem, Literatur und bildende Kunst. Ein Handbuch zur Theorie und Praxis eines komparatistischen Grenzgebietes, Berlin 1992, s. 11-31. Spojení výtvarného umění s literaturou (a také hudbou) je typickým výrazem touhy většiny romantických umělců po jednotném uměleckém díle (Gesamtkunstwerk). Srov. s textem Augusta Wilhelma Schlegela, publikovaný poprvé v časopise Athenäum v roce 1799 pod názvem Obraz (Die Gemälde): Lothar Müller (ed.), August Wilhelm Schlegel, Die Gemählde. Gespräch, Dresden 1996, s. 20. - Také např̀. Ludwig Tieck, Franz Sternbalds Wanderungen, Stuttgart 1994, s. 449. - Karl Brömel, Ludwig Tiecks Kunstanschauungen im „Sternbald“ (disertační práce), Universität Leipzig 1928, s. 20-21. Vztah nazarénů k textu byl navíc posílen jejich záměry ilustrovat krásnou literaturu. - Srov. Hans Joachim Neidhardt, Deutsche Malerei des 19. Jahrhunderts, Leipzig 1990, s. 10-11.

41 Grewe (pozn. 28), s. 36.

42 Viz mj. pozn. 38.

43 Srov. Hans Sedlmayr, Kunst und Wahrheit. Zur Theorie und Methode der Kunstgeschichte, Hamburg 1958, s. 90-91.

44 Srov. Matter - Boerner (pozn. 11), s. 193. 
Marii“. Franz Pforr se tímto tématem (téměř latentně) zabývá v části své básně Die Nacht bedeckte mich mit ihrem Grauen:

Und in dem Kelch stand lieblich schön ein Engel

Als reine Jungfrau keusch gekleidet da.

Die Rechte hielt den schwanken Lilienstengel

Und liebevoll der Jüngling sie ansah

Ich bin, sprach sie, die reine Himmelsliebe

Und bin beschieden deinem kreuschen Triebe. ${ }^{45}$

Pforrem deklarovaný smyslový až erotický (náznak prolínání tělesných substancí) vztah Panny (Marie) a archanděla (Gabriela) je zdánlivě kontrastní ke korektním, religiózním formulacím literárního ztvárnění této ikonografie od Friedricha Overbecka v básni Verkündigung:

Gegrüßet seyst du, o Maria, Gnadenreiche,

Gebenedeyte du vor Allen, sey gegrüßt!

da ist die Sunde daß die alte Nacht entweiche,

der Tag bricht endlich an; sey Morgenstern gegrüßt!

Bald geht in vollem Glanz hervor, o Makellose!

Die Sonne der Gerechtigkeit aus deinem Schooße! ${ }^{46}$

Obě básně, součásti společného adoračního vztahu nazarénů k Panně Marii a zároveň obdivu k sakralizované ženě, ženství a mateřství, se snaží být vyjádřením „božské lásky“ v jejím poměru k umění, ${ }^{47}$ bez dvojsmyslných záměrů, se snahou striktního vyvarování se možné libidózní interpretace. V tomto smyslu je potřeba doplnit výše zmíněný Pforrův text jeho dalším básnickým pokusem, nazvaným Du himmels Jungfrau, edle Kunst:

Wie ekel dünkt mich alle Lust

Und Freude dieser Welt

Nach dir nur drängt sich meine Brust

Un[d] nicht nach Gut und Geld. ${ }^{48}$

Jinou paralelu v souvislosti s literárním použitím námětu „Zvěstování Panně Marii“ nabízí ideové ztotožnění malíře Raffaela Santiho s rolí archanděla Gabriela, komponované dramatikem a básníkem úzce spjatým s počátky Svatolukášského bratrstva Friedrichem Ludwigem Zachariasem Wernerem: ${ }^{49}$

45 Ibidem, s. 96. Pforrův rukopis je uložen ve společné městské a univerzitní knihovně ve Frankfurtu nad Mohanem (Stadt- und Universitätsbibliothek, Frankfurt am Main, Ms. Ff. F. Pforr, 55/175-176).

46 Ibidem, s. 108. Overbeckův rukopis je zachován ve fondu městské knihovny v Lübecku (Stadtbibliothek Lübeck, Nachlaß Friedrich Overbeck V, 52, 3b). Zde cituji fragment, tzn. první část básně Friedricha Overbecka.

47 Srov. pozn. 11. Srov. také F. [rank] O. Büttner, Imitatio Pietatis. Motive der christlichen Ikonographie als Modelle der Verähnlichung, Berlin 1983, s. 70 ad., 120 ad.

48 Matter - Boerner (pozn. 11), s. 6.

49 Jochen Fried, Friedrich Ludwig Zacharias Werner, in: Walther Killy (ed.), Literaturlexikon. Bd. 12, Gütersloh - München 1992, s. 258-260. 
Ich führ'Euch Brüder, in die freud'gen Hallen,

Wo Raphael das Bild vom neuen Bunde

Als Evangelium uns hat verkündet; 50

Takto konstruovaná „aluze“ - splývání sakralizovaného umělce Raffaela Santiho $s$ archandělem Gabrielem (Rafaelem), event. evangelistou sv. Lukášem ${ }^{51}$ - přispěla rovněž k oblibě vizuální podoby této ikonografie u nazarénu․ ${ }^{52}$

\section{Nazaréni a výtvarné traktování ikonografie „Zvěstování Panně Marii“}

Téma „Zvěstování Panně Marii“ vyhovovalo Pforrovým a Overbeckovým záměrům, kladoucím ve výtvarném ztvárnění důraz na zjednodušený, lehce čitelný děj (související mj. se snahou absolutně se osvobodit od tehdejší „akademické manýry“), ${ }^{53}$ koncentrovaný zde navíc na pokorné až asketické přijetí poselství Boha ze strany Panny Marie.

„Zvěstování Panně Marii“, jako faktický prolog ke „štastně neštastnému“ křestanskému příběhu, hrálo svébytnou roli ve specifickém pojetí religióznosti u obou hlavních představitelů rané fáze nazarénského hnutí. Friedrich Overbeck jej vnímal v úzké vazbě na mystérium „zvěstování/zjevení, což se posléze prokázalo i jeho konvertováním ke katolické víře, zatímco Franz Pforr nahlížel na tento děj v intencích obecně „čisté“, mravní zbožnosti, nikoliv však již v prímé vazbě k církevnímu dogmatu, nýbrž jako vyjádření bytostné, lidské di̊stojnosti v Kantově a Schillerově smyslu. ${ }^{54}$ Tyto ideové tendence se dále promítaly do jejich výtvarných koncepcí, v Overbeckově případě je umění tvořeno jako zjevené „boží dílo“, 55 Pforr, a později Peter Cornelius je považují za vlastní umělcův tvůrčí počin, vzniklý ovšem pod „boží ochranou“. 56

50 Friedrich Ludwig Zacharias Werner, Ausgewählte Schriften. Poetische Werke. Gedichte bis zum Jahre 1810. Bd. 1, Bern 1970, s. 148. Cituji fragment ze začátku Wernerovy básně.

51 K ději „Zvěstování Panně Marii“ zaznamenanému evangelistou sv. Lukášem srov. Diego Arenhoevel Alfons Deissler - Anton Vögtle (edd.), Die Bibel. Die Heilige Schrift des Alten und Neuen Bundes. Deutsche Ausgabe mit den Erläuterungen der Jerusalemer Bibel, Freiburg - Basel - Wien 1969, s. 1444 (Lukáš, verš 26-38). - K interpretační analýze viz: Maria Elisabeth Gössmann, Die Verkündigung an Maria im dogmatischen Verständnis des Mittelalters, München 1957, s. 11-23. - Helène Papastavrou, Recherche iconographique dans l'art byzantin et occidental du XIe au XVe siècle l'annonciation, Venise 2007, s. 287-294. - K tématu vzájemného navazování až ztotožnění Raffaela s evangelistou sv. Lukášem v rámci nazarénského hnutí srov. Schlegel (Müller, pozn. 40), s. 123-124. - Schröter (pozn. 27), s. 319-322. - Elisabeth Schröter, Raffael und der Heilige Lucas. August Wilhelm Schlegels „Legende vom Heiligen Lucas": Wirkung und Quellen - Kunstgeschichte und Poesie im Dialog, Zeitschrift für Kunstgeschichte LXII, 1999, Heft 3, s. 418-431.

52 K metaforicko-alegorickým „proměnám“ a následným výkladům v souvislosti s ikonografí́ „Zvěstování Panně Marii“', např. Heinz Meyer, Metaphern des Psaltertextes in den Illustrationen des Stuttgarter Bilderpsalters, in: Christel Meier - Uwe Ruberg (edd.), Text und Bild. Aspekte des Zusammenwirkens zweier Künste in Mittelalter und früher Neuzeit, Wiesbaden 1980, s. 198-199.

53 Srov. Norbert Miller, Mutmaßungen über lebende Bilder. Attitüde und „tableau vivant“ als Anschauungsform des 19. Jahrhunderts, in: Helga de la Motte-Haber (ed.), Das Triviale in Literatur, Musik und Bildender Kunst, Frankfurt am Main 1972, s. 123.

54 Srov. Lehr (pozn. 12), s. 51.

55 Podobně: Jauslin (pozn. 4), s. 91. Manfred Jauslin popisuje instrumentalizaci této představy na př́ikladě cyklu litografií Sedm pohledù na okolí Salzburgu a Berchtesgaden od Ferdinanda Oliviera.

56 Lehr (pozn. 12), s. 52. 
Vývoj a postupné proměňování výtvarného traktování ikonografie „Zvěstování Panně Marii" se vyznačovalo od renesance, ${ }^{57}$ manýrismu, ${ }^{58}$ baroka a neoklasicismu nejenom značnou variabilitou v postojích i gestech Panny Marie a archanděla Gabriela (Panna Marie sedí, archanděl přilétá atd.), ${ }^{59}$ ale též změnami prostorových souvislostí, tzn. transformacemi celkové kompozice. $V$ umění nazarénů byly tyto tendence navíc obohaceny (nad rámec „standardních“ zobrazení novozákonního děje) o sekularizovanou polohu použitím tohoto tradičního křestanského námětu při komponování „portrétu“, „žánru“ a náboženské alegorie. ${ }^{60}$

Portrétní stylizace je v návaznosti na téma „Zvěstování Panně Marii“ v díle nazarénů zastoupena peruginsky traktovaným portrétem Franze Pforra od Johanna Friedricha Overbecka. ${ }^{61}$ [Obr. 3] Mladého, z obrazu hrdě vyhlížejícího umělce doplňuje na této kompozici v pozadí cudně skloněná ženská polopostava - Pforrova symbolická "nevěsta"62 $s$ atributy Panny Marie při „Zvěstování - s jehlicí, klubkem a kusem bílé látky (předením „opony chrámovéc), knihou (Starého zákona) a vázou s lilií. ${ }^{63}$

Projekce dvou vizuálních zobrazení (perspektivní „posunuti“ figur, event. zrcadlení) do jedné kompozice i přebírání symboliky severské renesance/pozdní gotiky obsažené v tomto portrétu nabízí bezprostřední náhled do pracovních postupů nazarénů a zároveň modelově prezentuje jejich sebereprezentační záměry, jak jsou popsány výše. ${ }^{64}$

„Žánrovým" výjevem, vycházejícím z předlohy „Zvěstování Panně Marii“a stylizovaným dokumentem ze života umělce s evidentní autobiografickou vazbou k tvůrci, ${ }^{65}$ je Pforrova

57 Gert Duwe, Der Wandel in der Darstellung der Verkündigung an Maria vom Trecento zum Quattrocento, Frankfurt am Main - Bern - New York - Paris 1988, s. 141-227. - Gert Duwe, Die Verkündigung an Maria in der niederländischen Malerei des 15. und 16. Jahrhunderts, Frankfurt am Main - Berlin Bern - New York - Paris - Wien 1994, s. 65-139. - Stefanie Renner, Die Darstellung der Verkündigung an Maria in der florentinischen Malerei. Von Andrea Orcagna (1346) bis Lorenzo Monaco (1425), Bonn 1996, s. 76-156. - Julia Liebrich, Die Verkündigung an Maria. Die Ikonographie der italienischen Darstellungen von den Anfüngen bis 1500, Köln - Weimar - Wien 1997, s. 48-78. - Sven Lüken, Die Verkündigung an Maria im 15. und frühen 16. Jahrhundert, Göttingen 2000, s. 41-92.

58 Dora Schumann, Die Darstellungen der Verkündigung in der italienischen Kunst der Renaissance (disertační práce), Universität Heidelberg 1910, s. 25-28, 36-37, 50-51, 59-64. - Daniel Arasse, L'Annonciation italienne. Une historie de perspective, Paris 1999, s. 266-294. - Anita Izcovich, Le corps précieux. Essai sur la peinture maniériste, Paris 2003, s. 83.

59 Srov. Klaus Schreiner, Maria. Jungfrau, Mutter, Herrscherin, München - Wien 1994, s. 116-117, 123.

60 Viz zde kapitolu II. Náboženská alegorie - výtvarný výraz nazarénské sebereprezentace.

61 Johann Friedrich Overbeck, Portrét Franze Pforra, 1810, olej, plátno, $62 \times 47 \mathrm{~cm}$, neznačeno, Staatliche Museen Preußischer Kulturbesitz - Nationalgalerie Berlin, inv. č. A II 381, NG 1002. - Gerhard Gerkens, Bildnis des Malers Franz Pforr, in: Andreas Blühm - Gerhard Gerkens (edd.), Johann Friedrich Overbeck. 1789-1869. Zwei zweihundertsten Wiederkehr seines Geburtstages (katalog výstavy), Museum für Kunst und Kulturgeschichte der Hansestadt Lübeck - Behnhaus 1989, s. 114.

62 Helmut Börsch-Supan, Deutsche Romantiker zwischen 1800 und 1850, München - Gütersloh - Wien 1972, s. 31. - Matter - Boerner (pozn. 11), s. 80. Pforrova charakteristika „vysněné nevěsty“ zní: „Eine reine und unschuldige Lilie ist meine Maria."

63 Srov. Matter - Boerner (pozn. 11), s. 58.

64 Dopis Friedricha Overbecka, datovaný 10. října 1810 a adresovaný do Vídně Josephu Sutterovi. Lehr (pozn. 12), s. 194-195. - Helmut Nickel, The Bride and the Cat: A Possible Source for Overbeck's Freundschaftsbild of Franz Pforr, Metropolitan Museum Journal, Volume 27/1992. Essays in Memory of Guy C. Bauman, s. 183-187.

65 Pforr vysvětluje práci na této kompozici slovy: „Wir hatten uns vorgenommen, daß jeder ein gemaltes Nachtstück auf eine gewisse Zeit liefern sollte. Ich malte dafür ein kleines Bildchen: ein Mann welcher nach Haus kommt und sein Weib bei der Arbeit findet; ich wählte diese ruhige häusliche Szene, weil das Bataillenmalen mir nicht mehr genügen wollte." Citaci z Pforrova deníku přejímám z Lehr (pozn. 12), s. 40 . 
kompozice nazvaná Noční návrat domů. ${ }^{66}$ [Obr. 4] Zde reprodukovaná, perem črtaná a lavírovaná skica k připravované, nedávno objevené olejové malbě, zachycuje figuru ženy, trpělivě čekající ve světnici na svého právě přicházejícího muže-malíre. Sekularizovaná Sponsa Dei je tak již plně proměněna v „pozemskou“, etablovanou manželku. ${ }^{67}$

Způsobem zasazení obou figur v kontrastně nasvíceném interiéru navazuje tato „Žánrová" scéna patrně na některou z ilustrací četných iluminovaných rukopisů pozdní gotiky, v nichž archanděl Gabriel netradičně přistupuje k Panně Marii z hloubky pravého rohu obrazového prostoru, ${ }^{68}$ event. na některou $\mathrm{z}$ devocionálií té doby. ${ }^{69}$ Evokuje současně srovnání s obrazem Zvěstování Panně Marii Lorenza Lotta, ${ }^{70}$ i když lze téměř vyloučit, že by Pforr tuto oltářní kompozici znal. ${ }^{71}$ Jak Pforrův konečný obraz, tak př́pravná kresba $\mathrm{k}$ němu prezentují noční interiérový výjev. V tomto kontextu působí jako vyrovnávání se s podobnou, v ději však skutečně antipodickou Lottovou expresivní, odstředivou kompozicí. Pforrova stylizovaná „pozemská žena“ očekává se sklopeným zrakem pozdní návrat svého muže s pokorou až pietou. Je s ním sice svázána v koncentrické figurální skupině, ale nevnímá ho, resp. komunikuje s ním jakoby prostřednictvím myšlenek. Tímto traktováním se tento profánní výjev svým výrazem mnohem více blíží „běžnému“ vyjádření ikonografie „Zvěstování Panně Marii“ (určitá psychologická

66 Franz Pforr, Noční návrat domů (Nächtliche Heimkehr), 1808, tužka, pero, tuš, papír, 156 x 127 mm, neznačeno, soukromá sbírka Alfred Winterstein Mnichov. Sieveking 1997, s. 100. Analýzou této př́ipravné studie se po technické stránce zabývá Jens Christian Jensen, Gedenkblatt für den Maler Franz Pforr, den Freund Friedrich Overbeck, in: Paul Brockhaus (ed.), Der Wagen 1963. Ein Lübeckisches Jahrbuch, Lübeck 1963, s. 87. - K dnes znovu objevenému (od roku 1924 nezvěstnému) olejovému obrazu srov. Friedrich von Boetticher, Malerwerke des neunzehnten Jahrhunderts, Bd. II/I (Zweiter Band / Erste Hälfte), Hofheim/Taunus 1979, s. 264. - Rose-Maria Gropp, Wiederkehr eines Verschollenen. Vorschau: Kunst und Kunstgewerbe bei Van Ham in Köln, Frankfurter Allgemeine Zeitung 12. November 2011, př́loha Kunstmarkt. Obraz byl v roce 2011 prodán v aukci v Kolíně nad Rýnem.

67 Srov. Franz Binder (ed.), [Margaret Howitt], Friedrich Overbeck. Sein Leben und Schaffen. Nach seinen Briefen und andern Documenten des handschriftlichen Nachlasses geschildert von Margaret Howitt. Erster Band: 1789-1833, Freiburg im Breisgau 1886, s. 65. Následný pobyt obou umělcủ v Rímě od roku 1810 prohloubil tuto představu obdivem k typu italské ženy, jako živoucí představitelky biblického děje.

68 Srov. napřr. Nicole Reynaud, Très Petites Heures d’Anne de Bretagne, in: François Avril - Nicole Reynaud (edd.), Les manuscrits à peintures en France 1440-1520 (katalog výstavy), Bibliothèque Nationale, Paris 1993, s. 266-267. - Nicole Reynaud, Heures à l'usage de Rome, in: François Avril - Nicole Reynaud (edd.), Les manuscrits à peintures en France 1440-1520 (katalog výstavy), Bibliothèque Nationale, Paris 1993, s. 268-270. Pforrovu systémovou návaznost na středověké vzory dokládají jeho slova ze zprávy o vlastním studiu (Studiumsbericht), které napsal mecenáši, panu Sarasinovi-Chironovi. - Lehr (pozn. 12), s. 43. - Hans-Joachim Ziemke, Franz Pforrs Studium Bericht, in: Hildegard Bauereisen - Martin Sonnabend (edd.), Correspondances. Festschrift für Margret Stuffmann zum 24. November 1996, Mainz 1996, s. 142. Franz Pforr podle mého názoru konkrétně pracoval s pozdně středověkou iluminací Barthélmyho d'Eyck, obsaženou v knize: Livre du Cuer d'Lamorous epris, cca 1460-1470, Cod. Vind. 2597, fol. 2r., Österreichische Nationalbibliothek, Vídeň.

69 Srov. Lüken (pozn. 57), s. 177, 209 a 263. V holandském malírství 15. století např̀. škola Dirka Boutse. M.[aurits] S.[meyers], Boodschap aan Maria. - Následník Dirka Boutse, ca. 1480, in: Maurits Smeyers (ed.), Dirk Bouts (ca. 1410-1475) een Vlaams primitief te Leuven (katalog výstavy), Sint-Pieterskerk en Predikherenkerk te Leuven 1998, s. 384. - Metodologické srov. Mirjam Neumeister, Das Nachtstück mit Kunstlicht in der niederländischen Malerei und Graphik des 16. und 17. Jahrhunderts. Ikonographische und koloristische Aspekte (disertační práce), Universität Bonn 1999.

70 Lorenzo Lotto, Zvěstování Panně Marii, 1526, 1527-1528 (?), kolem 1535, olej, plátno, $166 \times 114 \mathrm{~cm}$, signováno dole uprostřed: „L. Lotus“, Pinacoteca Comunale, Recanati, inv. č. nezjištěno. Tento obraz byl původně určen pro modlitebnu v Recanati (Oratorio della Confraternita di Santa Maria sopra Mercanti).

71 K potenciálním Pforrovým inspiracím ke kompozici Noční návrat domů viz Max Haase, Ein unvollendetes Aquarell Franz Pforrs, Städel-Jahrbuch, Neue Folge - Band II, 1969, s. 303-304. 
rozpačitost Panny Marie je obsažena v samé podstatě „Zvěstování“), než jak je tomu u historických kompozic např. benátské provenience. ${ }^{72}$

Zároveň jsou však tato Pforrova skica a obraz potvrzením důrazu kladeného nazarény na složitou symboliku, znesnadňující jednoznačné objasnění zobrazeného. Vedle látky zakrývající alkovnu, resp. okenní výklenek jako „chrámový“ závěs, hraje v tomto př́ípadě důležitou roli prázdná židle v levém dolním rohu kompozice, kam Lotto koncentruje vyděšenou a zároveň modlící se Pannu Marii. Společně s nepř́ímou, zprostředkovanou vzájemnou komunikací archanděla Gabriela a Panny Marie, resp. umělce (Pforra) s jeho „ženou“, lze interpretovat skutečný obsah Pforrem ztvárněného námětu nikoli jako „návrat“, nýbrž jako vysněný, tragicky neuskutečnitelný vztah mezi mužem a ženou. Oboustranná úcta, respekt a inspirace ${ }^{73}$ je tu doplněna jemným, téměř nezřetelným erotickým jiskřením, doložitelným vlastními Pforrovy slovy, evokujícími jeho ideál ženy, zpodobené později jako Marie na alegorickém obraze Sulamith a Marie. ${ }^{74}$ Tento výklad potvrzuje a současně doplňuje nedávno znovuobjevená olejová varianta této kompozice, na níž je přicházející malíř (Pforr) stylizován pomocí červeného pláště a klobouku v podobě svatozáře do figury Zmrtvýchvstalého Krista. Ikonografii „Zvěstování Panně Marii“ tak téměř cyklicky pointuje tématika Noli me tangere.

Tvůrčí propojení umění a života se stalo nejdůležitějším tématem raných děl nazarénského malírsství. Ideové hledání a ztvárnění „rodinného štěstí " promítnuté do náboženské ikonografie, ${ }^{75}$ bylo Franzem Pforrem kontrastně doplněno zpodobením další přrirozené součásti lidského bytí, alegorickým „zvěstováním“ smrti (umělci), snad i jako důsledek jeho osobního pocitu či předtuchy nevyléčitelného onemocnění. ${ }^{76}$ Nejdrastičtěji je vyjádřeno v tužkové kresbě, na níž středověký malíř v ateliéru tvoří obraz sedící $M a-$ donny dell'Umiltá. Ta se ale zjevuje současně trůnící na oblaku společně se žehnajícím Ježíšem Kristem. Tento výjev významově naplňuje gestikulace kostlivce ozdobeného vavřínovým věncem. Tento „prostředník“ mezi umělcem a nebeskou sférou dává této kompozici jednoznačný výklad, poukazující na fragilitu lidského života a věčnou slávu uměleckého tvoření. ${ }^{77}$

Syntetickou podobu dostalo použití námětu „Zvěstování Panně Marii“ u nazarénů v náboženské alegorii, pokusu vyjádřit společné tvưrčí a životní záměry, sjednotit

72 Louisa C. Matthew, Method and meaning in an altarpiece by Lorenzo Lotto, Renaissance Studies VIII, 1994, č. 2, June, s. 165. - Jacqueline Olson Padgett, Ekphrasis, Lorenzo Lotto's Annunciation, and the hermeneutics of suspicion, Religion and the Arts, Volume 10/2, 2006, s. 191-201.

73 Sonnabend (pozn. 20), s. 60.

74 Srov. Binder - Howitt (pozn. 67), s. 90. - Lehr (pozn. 12), s. 55-56. Lehr se domníval, že Pforr se $\mathrm{v}$ tomto př́padě inspiroval sestrou Johanna Konrada Hottingera Regulou.

75 7. kapitola Pforrovy (a Overbeckovy) Knihy Sulamith a Marie (Das Buch Sulamith und Maria) z edice Matter - Boerner (pozn. 11), s. 80.

76 Např. Lehr (pozn. 12), s. 51 a 187. Společně s invokací žádá Franz Pforr Boha o milosrdnou smrt slovy: „Herr nimm mich auf zu Dir.“

77 Franz Pforr, Malír a smrt, 1810, tužka, papír, $153 \times 111 \mathrm{~mm}$, monogramováno a datováno vpravo dole: „F. P. Rom 1810“, Kurpfälzisches Museum der Stadt Heidelberg, inv. č. Z 5189 (ze sbírek Stift Neuburg bei Heidelberg). - Lehr (pozn. 12), s. 178-179, 347. Obdobná kompozice Učenec a smrt byla kopírována Pforrem roku 1810 ze „Stammbuchu“ dvorního rady Büela. Pforr navazoval v tomto př́ípadě formálně i ikonograficky na typus pozdně středověkých Tancủ smrti, populárních např. díky již před koncem 18. století zaniklému freskovému (?) cyklu Hanse Holbeina ml. Na zdi hřbitova v Basileji, a širrený dřevořezovými reprodukcemi. O tomto uměleckém díle pozdní gotiky se dochovaly zmínky i v Pforrově korespondenci s Johannem Davidem Passavantem. 
umělecké protiklady a zároveň zvěčnit vzájemné „přátelstvi“" 78 s možnými přesahy do širších společenských souvislostí. ${ }^{79}$ Jednoznačným reprezentantem v tomto smyslu je Pforrův programový obraz nazvaný Sulamith a Marie. ${ }^{80}$ [Obr. 5]

Stejně jako u ideově podobného, předcházejícího, pouze v kresbě a následné litografii realizovaného Pforrova uměleckého záměru Alegorie prótelství z roku $1808^{81}$ (výrazu kolegiality, vzájemného obdivu a obohacení v osobních vztazích Franze Pforra, Johanna Friedricha Overbecka a Johanna Davida Passavanta ${ }^{82}$ a v pozdějším, podobně programovém výjevu Italie a Germanie, ${ }^{83}$ tentokrát od Johanna Friedricha Overbecka, navazuje na tradiční křestanskou ikonografii. Pforrova kompozice Sulamith a Marie nejenom rozvíjí příběhy Navštívení Panny Marie a Zvěstování Panně Marii v rámci výtvarného záměru harmonického spojení forem severského a italského umění, tedy aluzí na mariánský děj, nýbrž je také př́imým projevem nazarénského kultu Panny Marie. Navíc v sobě tento obraz obsahuje rozpracování tématiky dalších „Zvěstování“. V případě Sulamith (levé části diptychu Sulamith a Marie) „Zvěstování pastýřům“, 84 odkazujícím možná ještě na „strategie“ dětských her hlavních představitelů nazarénského hnutí. ${ }^{85}$

Obrazová kompozice Pforrovy Sulamith a Marie odkazuje dvoudílnou formou tohoto díla menších rozměrů, zakončeného lomenými oblouky, na východiska-koncepty

78 „Přátelstvi“ je míněno také ve smyslu a souvislostech křestanské ctnosti. Srov. Jensen (pozn. 66), s. 90-91.

79 Ibidem, s. 91. Jensen, zdůrazňující nazarénské identifikační sebevymezení, zde opomíjí konotace sociální a kulturní sebepropagace.

80 Franz Pforr, Sulamith a Marie, 1811, olej, dřevěná deska, $34,5 \times 32 \mathrm{~cm}$, neznačeno, Museum Georg Schäfer, Schweinfurt, inv. č. MGS 1183. Jensen 2000, s. 174-176. K př́ípravným kresbám k tomuto obrazu: Lehr (pozn. 12), s. 192 a 350.

81 Franz Pforr, Alegorie prátelství mezi Franzem Pforrem, Johannem Friedrichem Overbeckem a Johannem Davidem Passavantem (Allegorie der Freundschaft), 1808, tužka, papír, $242 \times 187$ mm, neznačeno, Städelsches Kunstinstitut, Frankfurt nad Mohanem, inv. č. 15923 (př́pravná skica). - Franz Pforr, Alegorie přátelství mezi Franzem Pforrem, Johannem Friedrichem Overbeckem a Johannem Davidem Passavantem (Allegorie der Freundschaft), 1808, pero, černá tuš, papír, $247 \times 193$ mm, vlevo uprostřed ve štítku datováno: „1808“; na parapetní zídce pod oknem popsáno: „POP“, Städelsches Kunstinstitut, Frankfurt nad Mohanem, inv. č. 4 (kopie vyhotovená pro J. D. Passavanta). Lehr (pozn. 12), s. $103-104$ a 342.

82 Ibidem, s. 30-31. O problematičnosti tohoto přátelství, dané především rozdílnými př́ístupy k uměleckému školení, viz ibidem, s. 33-34 (citace z již zmíněného Pforrova Studiumsbericht). K dobovému kultu „přátelstvi““ a „prrátelské služby“ ibidem, s. 58.

83 Johann Friedrich Overbeck, Italie a Germanie, 1811-1820, olej, plátno, 94 × 104,3 cm, neznačeno, Bayerische Staatsgemäldesammlungen, Neue Pinakothek, Mnichov, inv. č. WAF 755 (konečná verze obrazu).

84 Metodologicky se touto otázkou zabývá např. Liebenwein-Krämer (pozn. 7).

85 Pforr např. vzpomíná v korespondenci svému příteli Passavantovi na společné hraní divadla („Schattenspiel“, „Laterna magica“, „Schauspiel“). Lehr (pozn. 12), s. 5. „Nezatížená dětskost“ jako alternativa k racionalismu osvícenství vyplývá také z následujícího Pforrova vyjádření: „Mit der Aufklärung, deren Nutzen gewiß in vielem ganz unleugbar, bin ich nicht ganz zufrieden, insofern sie nämlich von dem kindlichen Glauben abführt, der nach meinem Gefühl den Menschen glücklich und selig macht..."Ibidem, s. 53. 
domácích, event. cestovních gotických oltářních, ${ }^{86}$ resp. devočních obrazů. ${ }^{87}$ Ikonograficky se jedná o zpodobení textového, „pohádkově-religiózního“ concetta ${ }^{88}$ nazvaného Kniha Sulamith a Marie (Das Buch Sulamith und Maria). ${ }^{89}$ V něm Pforr (a Overbeck) popisují své imaginární nevěsty (deskripce ženské tělesné a charakterové krásy) ${ }^{90}$ a modelují tak umělecký ideál (Idealgestalt), který je třeba vnímat nejen ve výtvarných, ale též v psychologických a sociálních souvislostech. „Overbeckova“ Sulamith je zasazena do italské, př́mořské (?) krajiny s antickou a středověkou architekturou, event. spolia. ${ }^{91}$ „Pforrova“ Marie naproti tomu ztělesňuje prostou německou dívku - podle jeho vlastních slov čistou, neposkvrněnou, charakterizovanou bílou zástěrou, ${ }^{92} \mathrm{v}$ evidentní aluzi či vztahu k Panně Marii, a to i jako té, která ví o konečném osudu Ježíše Krista (zapojení Pforrových melancholických nálad a myšlenek o smrti). ${ }^{93}$ (Panna) Marie sedí v pozdně středověkém interiéru, v němž nechybí její atributy při „Zvěstování. Přítomna je také kočka, která se vyskytuje již na Overbeckově Portrétu Franze Pforra ${ }^{94}$ [Obr. 3] - doposud nikoli přesvědčivě interpretovaný ikonografický moment, občas se objevivší na výjevech „Zvěstování Panně Marii“.

Mužská postava zahalená do modrého pláště (portrét Johanna Friedricha Overbecka) v pozadí levé části kompozice se Sulamith, hraje roli sekularizovaného pastýře přicházejícího adorovat Pannu Marii s právě narozeným Kristem. Připomíná ale také figuru sv. Josefa (možná aluze na „Josefa“ zmiňovaného v textové předloze), ${ }^{95}$ který

86 Ke srovnání např. dvoudílná, na dřevě malovaná podoba výjevu „Zvěstování Panně Marii“ od anonymního nizozemského mistra z okruhu Huga van der Goes se znázorněním archanděla Gabriela na levém a Panny Marie na pravém kř́dle. U.[rsel] Schönrock - H.[ans] - W.[erner] Grohn, Skulpturenabteilung, Gemäldegalerie. Staatliche Museen zu Berlin, Berlin 1953, s. 8, 26. - Friedrich Winkler, Das Werk des Hugo van der Goes, Berlin 1964, s. 226-229. - Rudolf Preimesberger, Zu Jan van Eycks Diptychon der Sammlung Thyssen-Bornemisza, Zeitschrift für Kunstgeschichte LIV, 1991, Heft 4, s. 459-489. - Margaret L. Koster, Hugo van der Goes and the procedures of art and salvation, Turnhout 2008, s. 66-69.

87 K pojmu devoční obraz v tomto smyslu Thomas Noll, Religiöse Verehrung und ästhetischer Genuß. Zur Wahrnehmung von Bildern im späten Mittelalter, in: Sabine Arend - Daniel Berger - Carola Brückner et al. (edd.), Vielfalt und Aktualität des Mittelalters. Festschrift für Wolfgang Petke zum 65. Geburtstag, Bielefeld 2006, s. 403-424. Tento text je analyzován v edici Matter - Boerner (pozn. 11) s. 75-89.

Srov. s pátou kapitolou knihy Das Buch Sulamith und Maria (Matter - Boerner /pozn. 11/, s. 78-79). Zdrženlivá, pouze v náznacích obsažená erotická složka byla Pforrem z definitivní varianty textu nakonec vypuštěna, srov.: „Wo bist Du meine holde Freundin? ... Mein Herz schreyet nach Dir, Sulamith! ...süße Freundin! ..." (Matter - Boerner. pozn. 11, s. 85).

91 Reiter (pozn. 33), s. 54.

92 Viz pozn. 74.

93 Srov. pozn. 76.

94 Srov. Lehr (pozn. 12), s. 291.

95 Míněna je souvislost s evangeliem sv. Lukáše: „[Joseph] ... schlug er die Bibel um und fand die Stelle im heiligen Evangelisten Lukas, wo geschrieben steht: Und im sechsten Monat ward der Engel Gabriel gesandt von Gott in eine Stadt in Galiläa, die heißt Nazareth zu einer Jungfrau, die vertraut war einem Manne mit Namen Joseph vom Hause Davids, und die Jungfrau hieß Maria." Matter - Boerner (pozn. 11), s. 75. K proměnám mariánské ikonografie a k sebeidentifikaci umělce s poutníkem-svědkem „svatého děje“ mateřství srov. např̀. báseň Johanna Wolfganga Goethe Poutník (Der Wanderer) z přelomu let 1771-1772. Výtvarně je zhmotněná např. v obraze Ernsta Förstera Poutník (Der Wanderer), 1832, olej, dřevěná deska, 56 x $42 \mathrm{~cm}$, monografováno a datováno uprostřed kompozice (na kmeni platanu): „EF 18...“ (konec letopočtu nečitelný), Städtische Galerie im Lenbachhaus und Kunstbau, inv. č. G 4430. Barbara Eschenburg, Vom Spätmittelalter bis zur Neuen Sachlichkeit. Die Gemälde im Lenbachhaus München, München, Berlin 2009, s. 29 a 242. Podobný obraz vytvořil také Franz Ludwig Catel v roce 1831. 
je svědkem již naplněného „Zvěstování“. Naopak „Pforrova“ Marie marně čeká ve své světnici: archanděl Gabriel, tzn. případný Pforrův autoportrét, přítomen není. Místo něj je navíc v horní části obrazu (ve cviklu) zpodoben sv. Jan Evangelista, ${ }^{96}$ opětovný zástupný symbol Overbecka. ${ }^{97}$ Pforr tímto způsobem poukazuje mj. nejen na svou blížící se smrt, která bude jeho vykoupením, ale také přímo na svou identifikaci s pašijovým příběhem Ježíše Krista, jak to ostatně naznačuje již na výše zmíněné kompozici s dosavadním názvem Noční návrat domů. [Obr. 4]

Pforrův a Overbeckův text Sulamith a Marie, předčítaný a reprezentovaný Johannem Friedrichem Overbeckem v kruhu středoevropských umělců v Ř́mě po Pforrově smrti v roce 1812, nepochybně přispěl vedle svého vizuálního ztvárnění k pozdější popularitě ikonografie „Zvěstování Panně Marii“ mezi malíri nazarénské orientace. Sám Overbeck se k tomuto tématu vrátil opět dvoudílnou a podobně architektonicky rámovanou kompozicí Zvěstování Panně Marii - Navštívení Panny Marie (ilustrující - byṫ nikoli věrně slova evangelia sv. Lukáše), akvarelu, dnes umístěném v Musée San Carlos v Mexico $\mathrm{City}^{98}$ a určeném pro hamburského obchodníka H. Nolteho ${ }^{99} \mathrm{z}$ roku $1814 .{ }^{100} \mathrm{I}$ k tomuto výjevu se zachoval literární doprovod, báseň od Friedricha Overbecka spojená s adorací Panny Marie. ${ }^{101}$

Následné nazarénské obrazy zpodobující a ikonograficky variující „Zvěstování Panně Marii“ zmiňuji vzhledem k jejich množství pouze ve výběrovém přehledu. Zvěstování Panně Marii od Julia Schnorra von Carolsfeld z roku $1820^{102}$ je mezistupněm k vývoji ve 20. letech 19. století a dále rozvádí Pforrův koncept Sulamith a Marie ${ }^{103}$ stejně jako kompozice, vzniklé v bezprostředním kontaktu s Overbeckovým římským ateliérem v uměleckém okolí mistra z Lübecku, představovaným Johannem Evangelistou Schef-

96 Evangelium sv. Jana neobsahuje děj „Zvěstování Panně Marii“.

97 Srov. pozn. 25.

98 Spickernagel (pozn. 30), s. 122.

99 Binder - Howitt (pozn. 67), s. 473. - Michael Thimann, Notwendige Arabesken bei den Nazarenern. Zu Friedrich Overbeck, Verkündigung und Heimsuchung (1814/1816), Das Münster. Zeitschrift für christliche Kunst und Kunstwissenschaft LXV, 2012, č. 2, s. 118-125.

100 Př́pravná tužková kresba k této kompozici: Johann Friedrich Overbeck, Zvěstování Panně Marii - Navštívení Panny Marie, 1814, tužka, papír, $304 \times 408$ mm, monografováno a datováno v pravém dolním rohu: „FO 1814“, Kunstmuseum, Basel, inv. č. 1867.52. S.(igrid) M.[etken], Verkündigung und Heimsuchung, in: Klaus Gallwitz (ed.), Die Nazarener in Rom. Ein deutscher Künstlerbund der Romantik (katalog výstavy), Galleria Nazionale d’Arte Moderna, Roma 1981, s. 166. - G.[erhard] G.[erkens], in: Blühm - Gerkens (pozn. 61), s. 203-204. Srov. také Matter - Boerner (pozn. 11), s. 200. Litografie vytvořená podle této kompozice o rozměrech $30,7 \times 41,2 \mathrm{~cm}$ z lipského Museum der bildenden Künste (inv. č. NI 2008) byla publikována v Claude Keisch (ed.), Classici e romantici tedeschi in Italia (katalog výstavy), Ala Napoleonica Venezia 1977, s. 84. Fotografii konečného akvarelu z mexického muzea San Carlos publikoval Michael Thimann (pozn. 99).

101 Srov. pozn. 95.

102 Julius Schnorr von Carolsfeld, Zvěstování Panně Marii, 1820, olej, plátno, $120 \times 92 \mathrm{~cm}$, monogramováno a datováno vpravo dole: „18 J. S. 20“, Staatliche Museen Preußischer Kulturbesitz, Nationalgalerie, Berlin, inv. č. A I 895 NG 1060. Herwig Guratzsch (ed.), Julius Schnorr von Carolsfeld 1794-1872 (katalog výstavy), Museum der bildenden Künste Leipzig 1994, s. 211-212. - Michael Teichmann, Julius Schnorr von Carlolsfeld (1794-1872) und seine Ölgemälde. Monographie und Werkverzeichnis, Frankfurt am Main 2001, s. 22, 89-94.

103 Srov. Lehr (pozn. 12), s. 198. 
ferem von Leonhardshoff, ${ }^{104}$ Philippem Veitem, ${ }^{105}$ Juliem Oldachem, ${ }^{106}$ Theodorem Rehbenitzem ${ }^{107}$ a dalšími malíři. Tématem „Zvěstování Panně Marii“ se zabývali také např. Franz Horny, ${ }^{108}$ pozdní nazaréni Theodor Weller, Josef von Führich, Ernst Deger, ${ }^{109}$ Johann von Schraudolph a Francouz Louis Grimaux, ${ }^{110}$ stejně jako přítel Josefa Vojtěcha Hellicha z Ríma, rakouský malír Gebhard Flatz. ${ }^{111}$

\section{Nazarénské strategie jako výraz emancipujícího se uměleckého života v Praze předbřeznové doby - Josef Vojtěch Hellich

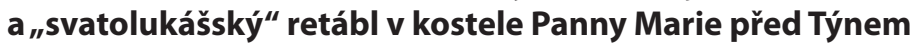

Ačkoli se formy nazarénského umění ve středoevropském prostředí ve 20. a 30. letech 19. století postupně zcela etablovaly na výzdobě interiérů i exteriérů budov v bavorském rezidenčním městě Mnichově, 112 a sebereprezentačního definování ani propagace opodstatňující uměleckou tvorbu již nebylo z tohoto důvodu potřeba, nezanikly výše naznačené, původně specificky individuální, sebeidentifikační tendence, ale rozvíjely se i po smrti Franze Pforra. ${ }^{113}$ Ta ovšem znamenala zánik tvůrčí dvojice Pforr - Overbeck.

Pražská mladá malírská generace se od začátku 2. třetiny 19. století koncentrovala - i v rámci vymezování se vưči oficiálním kruhům reprezentujícím Akademii umění - právě na tyto prvotní myšlenkové, výtvarně ztvárněné strategie Svatolukášského bratrstva. Klíčovou osobností zprostředkovávající v Praze 30. let 19. století tyto vlivy byl rodák ze severočeské Chrastavy Josef von Führich, ${ }^{114}$ který byl společně s Johannem Friedrichen Overbeckem autorem části konceptu figurální výmalby tzv. Tassova sálu ř́mského Cassina Massima. ${ }^{115}$ Führich ovlivnil tvorbu pozdějšího hlavního představitele

104 Srov. Michael Krapf - Hans Bisanz, Johann Evangelist Scheffer von Leonhardshoff 1795-1822. Ein Mitglied des Lukasbundes aus Wien (katalog výstavy), Obere Belvedere - Österreichische Galerie, Historisches Museum der Stadt Wien 1977, s. 154-155.

105 Norbert Suhr, Philipp Veit (1793-1877). Leben und Werk eines Nazareners. Monographie und Werkverzeichnis, Weinheim 1991, s. 277 a 326.

106 Srov. Alfred Lichtwark, Julius Oldach, Hamburg 1899, s. 110-114. Oldach pod vlivem Petera von Cornelia transformuje v tomto smyslu výjev Goethova Dr. Fausta nebo lidové legendy Dr. Faustuse. Julius Oldach, Mefisto a žák, 1828, olej, dubová deska, $26 \times 20 \mathrm{~cm}$, monogramováno a datováno vlevo dole: „13. Dz. JO 1828“, Kunsthalle Hamburg, inv. č. nezjištěno.

107 Telse Wolf-Timm, Theodor Rehbenitz 1791-1861. Persönlichkeit und Werk, Kiel 1991, s. 202, 220-222, 247-248 a 259-260.

108 Hornyho tužková kresba publikována v Walther Scheidig, Franz Horny. 1798 Weimar - Olevano 1824, Berlin 1954, s. 40 a 169.

109 Karl Koetschau, Einige Kartons und Bilder von Ernst Deger, Düsseldorf (cca 1925), s. 12-13.

110 Pia Müller-Tamm, Nazarenische Zeichenkunst (katalog výstavy), Städtische Kunsthalle Mannheim 1993, s. 44.

111 Elmar Vonbank (ed.), Gebhard Flatz 1800-1881 (katalog výstavy), Marktgemeinde Wolfurt 1982, s. 97.

112 Herbert von Einem, Die Ausmalung der Festsäle durch Peter Cornelius, in: Klaus Vierneisel - Gottlieb Leinz (edd.), Glyptothek München 1830-1980 (katalog výstavy), Glypthotek München 1980, s. 214-233. - Frank Büttner, Peter Cornelius. Fresken und Freskenprojekte. Band 1, Wiesbaden 1980, s. 125-223.

113 Franz Pforr zemřel v Albanu 16. 6. 1812 ve věku 24 let.

114 Srov. Řezáč (pozn. 1), s. 34.

115 Ibidem, s. 6. 
nazarénských forem v Čechách Josefa Vojtěcha Hellicha, ${ }^{116}$ a to ještě před jeho odjezdem do Ríma v roce $1836 .{ }^{117}$ Führich vedl v Praze v této době neformální kroužek umělců s nimiž pěstoval Hellich intenzivní vztahy -, dávající původním nazarénským koncepcím nové obsahy. ${ }^{118}$

Konečným, byt’ opožděným výrazem těchto snah byl Hellichem komponovaný a následně i namalovaný oltářní obraz - dílo reprezentující širší spektrum pražských umělců, včetně možné počáteční podpory ze strany pražské Akademie. Tato oltářní archa pozdně gotických forem se středovou kompozicí Sv. Lukáš malující Pannu Marii, zasvěcená sv. Lukáši, je umístěna v levé boční lodi kostela Panny Marie před Týnem na Starém Městě pražském. ${ }^{119}$ [Obr. 7]

Josef Vojtěch Hellich v tomto případě navazuje na své nazarénské předchůdce podobným kódováním děje, transformováním ikonografie a výtvarných forem, naznačováním latentního nezobrazeného př́běhu přítomného pouze v rozvržení figurální kompozice, event. díky vložení detailu se symbolickým významem. Současně ale usiluje o zachování jednoznačného působení výjevu jak v souvislostech katolického liturgického provozu (homogenita celkové ideové koncepce oltářní archy, rozvedené na malbách bočních křídel retáblu, k nimž je středový obraz prologem), tak v souvislosti sociálněreprezentativní snahy o „legitimizování patrona malírư sv. Lukáše, a tím manifestaci tehdejšího pražského (spolkového) uměleckého života v celé šíri jeho složitosti. ${ }^{120}$

Hellich v průběhu práce na tomto svém syntetickém díle kombinuje a variuje historická zobrazení. ${ }^{121}$ Rozmístuje aktéry děje v prostoru tak, aby sv. Lukáš bud' připomínal (také postojem a gesty) archanděla Gabriela (i v možném smyslu sv. Lukáše jako bezprostředního svědka "Zvěstování Panně Marii“), ${ }^{122}$ anebo jej zaměňuje v roli za tradičně sedící Pannu Marii. Ta se zde zjevuje, až přilétá naopak jako „božský posel“ na oblaku. ${ }^{123}$ Zároveň ale, vycházeje z bohatého výtvarného repertoáru předcházejících epoch, z nichž klíčová je pro tento prrípad Pintoricchiova freska v kostele Santa Maria Maggiore v umbrijském Spellu, ${ }^{124}$ popularizovaná ve 20. letech 19. století grafikou

116 Ibidem, s. 20-26.

117 Ibidem, s. 34-35.

118 Ibidem, s. 34-35 a 42.

119 Ibidem, s. 40.

120 Postup Hellichova přemýšlení o figurálních kompozicích týnského „svatolukášského“ retáblu, je doložitelný na jedinečně zachovaném konvolutu přípravných kreseb z Grafické sbírky Národní galerie v Praze. Za technické konzultace při studiu děkuji Ondřeji Chrobákovi. O popis a částečné rozkrytí pozadí vzniku tohoto Hellichova díla se přede mnou pokusil Dyk 1960.

121 Srov. pozn. 57, 58, 59.

122 Srov. [J.(ohann) D.(avid) Passavant], Rafael von Urbino und sein Vater Giovanni Santi von J. D. Passavant. In zwei Theilen mit vierzehn Abbildungen. Erster Theil, Leipzig 1839, s. 479. - Annamaria Rossi, Benedetto Bonfigli, Annunciazione e san Luca, in: Vittoria Garibaldi (ed.), Un pittore e la sua città. Benedetto Bonfigli e Perugia (katalog výstavy), Galleria Nazionale dell'Umbria, Perugia 1996, s. 166. - Arasse (pozn. 58), s. 171-175.

123 Traktování známé z nespočetných příkladů manýristického a barokního umění (např. kompozic boloňské školy).

124 Passavant (pozn. 122), s. 505-506. - Scarpellini - Silvestrelli (pozn. 17), s. 212-220. - Daniela Bohde, „Le tinte delle carni“. Zur Begrifflichkeit für Haut und Fleisch in italienischen Kunsttraktaten des 15. bis 17. Jahrhunderts, in: Daniela Bohde - Mechthild Fend (edd.), Weder Haut noch Fleisch. Das Inkarnat in der Kunstgeschichte, Berlin 2007, s. 53-54. - Corrado Fratini - Giulio Proietti Bocchini, Gli affreschi della capppella Baglioni nella collegiata di Santa Maria Maggiore a Spello, in: Vittoria Garibaldi - Francesco Federico Mancini (edd.), Pintoricchio (katalog výstavy), Galleria Nazionale dell'Umbria, Perugia 2008, s. 113-114. 
od Bartolomea Pinelliho, ${ }^{125}$ přenáší Hellich na svou kompozici čtenářský pultík Panny Marie. Tento systémově zástupný předmět fakticky neprrítomné ikonografie [Obr. 7] ${ }^{126}$ konkrétně odvodil podle jím vyhledané a studované oltářní desky Antoniazza Romana umístěné v kapli Zvěstování Panně Marii (Capella dell'Annunziata) kostela Santa Maria sopra Minerva v Rímě. ${ }^{127}$ [Obr. 8] Tento specifický kus nábytku účelovým způsobem časově zasazuje umělce a zároveň evangelistu sv. Lukáše do chvíle, kdy prostřednictvím „božského vnuknuti“" a „vnitřního zraku“ zaznamenává děj „Zvěstování Panně Marii“ nejen malířsky, ale i literárně. Podobně - tentokrát profanizováním křestanského tématu - stupňuje svůj pikantní obrazový výraz použitím pultíku Panny Marie např. francouzský malíř Jean Auguste Dominique Ingres ve své kompozici Paolo a Francesca. ${ }^{128}$ [Obr. 6] Dvojice literárních milenců v tomto Ingresově podání nejenom vychází z děje „Zvěstování Panně Marii“, navíc zde francouzský mistr téměř cituje Pforrovu figuru Raffaela z výše zmíněné kompozice Albrecht Dürer a Raffael, klečící v adorační modlitbě před personifikovaným trůnícím Uměním. [Obr. 2]

Josef Vojtěch Hellich usiloval stejně jako nazaréni zprostředkovat svoje záměry širší veřejnosti také pomocí textu, ten však bohužel nebyl nakonec publikován. Autor týnského retáblu jeho obsah ale nepochybně šiřil ve vzájemné osobní komunikaci se svými malířskými kolegy. ${ }^{129}$

125 Luigi Sensi, Bartolomeo Pinelli, Riproduzione grafica della capella Baglioni, in: Vittoria Garibaldi Francesco Federico Mancini (edd.), Pintoricchio (katalog výstavy), Galleria Nazionale dell'Umbria, Perugia 2008, s. 290-291, 411. - Řezáč (pozn. 1), s. 47.

126 Josef Vojtěch Hellich, Sv. Lukáš malující Pannu Marii s Ježiškem, 1846, tužka, pero, černá tuš, papír, 264 × $212 \mathrm{~mm}$, značeno a datováno v pravém horním rohu: Hellichova značka (antický kahan) a „1846“, Grafická sbírka Národní galerie v Praze, inv. č. K 21773. Tato varianta nebyla Hellichem nakonec použita při realizování definitivní malby.

127 Antoniazzo Romano, Zvěstování Panně Marii (kombinované s motivem Panny Marie rozdávající almužny chudým dívkám, které doporučuje kardinál Juan de Torquemada, 1500, tempera, dřevěná deska, $130 \times 185 \mathrm{~cm}$, signováno a datováno: „DIE. XX. MARTII. MCCCCC.ANTONATIUS ROMANUS PINXIT“, Santa Maria sopra Minerva, capella dell’Annunziata, Rím. Gisela Noehles-Doerk, Antoniazzo Romano. Studien zur Quattocentomalerei in Rom (disertační práce), Westfälische Wilhelms-Universität Münster 1973, s. 80-82. - Antonio Paolucci, Antoniazzo Romano. Catalogo completo, Firenze 1992, s. 146. - Anna Cavallaro, Antoniazzo Romano e gli Antoniazzeschi. Una generazione di pittori nella Roma del Quattrocento, Udine 1992, s. 120-123, 203-204. - Claudio Strinati, Linee di tendenza nella pittura a Roma del Quattrocento, in: Maria Grazia Bernardini - Marco Bussagli (edd.), Il'400 a Roma. La rinascita delle arti da Donatello a Perugino (katalog výstavy), Museo del Corso, Roma 2008, s. 38-39. - Anna Cavallaro, Antoniazzo Romano, in: Maria Grazia Bernardini - Marco Bussagli (edd.), Il'400 a Roma. La rinascita delle arti da Donatello a Perugino (katalog výstavy), Museo del Corso, Roma 2008, s. 169-173.

128 Jean Auguste Dominique Ingres, Paolo a Francesca (Paolo et Francesca), 1819, olej, plátno, $48 \times 39$ cm, signováno a datováno vlevo dole: „INGRES.ROM. 1819“, Musée des Beaux-Arts d'Angers, inv. č. MTC 19 (další varianty v muzeu v Bayonne a soukromých sbírkách). Daniel Ternois - Ettore Camasasca, Tout l'oeuvre peint d'Ingres, Paris 1971, s. 96 a 112. - Claudio Poppi (ed.), Sventurati amanti. Il mito di Paolo e Francesca nell'800 (katalog výstavy), Museo della città, Rimini 1994, s. 112. K začínající diskuzi o vzájemném ovlivňování nazarénského umění a francouzského umění Ingresova okruhu např. Rachel Esner, Auf der Suche nach verlorenen Zeit. Überlegungen zu Overbeck und Ingres, in: Blühm - Gerkens (pozn. 61), s. 54-62.

129 Řezáč (pozn. 1), s. 54. 


\section{Dozvuk obliby „nazarénské“" ikonografie „Zvěstování Panně Marii“" v díle Josefa Mánesa}

O dosahu autority Hellichova „svatolukášského“ obrazu a nazarénských koncepcí130 u širší pražské umělecké veřejnosti ${ }^{131}$ svědčí také vliv na Josefa Mánesa, malíre, který od konce 30. let 19. století podobně navazoval na idealizovaně stylizované figurální formy. ${ }^{132}$ Hellichova ikonografická „hra“ v jeho programovém obraze, která v 60. letech 19. století pomalu upadala v zapomnění, našla rezonanci v Mánesově dlouholetém vyrovnávání se s tímto dílem.

Mánes na konci svého uměleckého i biologického života - inspirován mj. rozsáhlou tvorbou oltáŕních obrazů Josefa Vojtěcha Hellicha při výzdobě kostela sv. Cyrila a Metoděje $\mathrm{v}$ Karlíně a těsně předtím $\mathrm{v}$ neuskutečněném projektu úpravy interiéru pražské rotundy sv. Kříže - ilustroval dopis řezbáři Josefu Vorlíčkovi ${ }^{133}$ návrhem trojdílné oltářní archy, na níž je ve středové kompozici zamýšleno zobrazení „Zvěstování Panně Marii“. [Obr. 9] Kompozice i architektonické tvarosloví navazují na Hellichův týnský retábl, včetně zde analyzovaného reprezentačního významu tohoto tématu v rámci nazarénské umělecké sebeidentifikace. ${ }^{134}$

Pouze letmo črtaná, přesto synteticky pojatá Mánesova perokresba navazuje především na oltářní desky a nástěnné malby Filippina Lippiho, uchovávané v Hellichově oblíbené kapli římského kostela Santa Maria sopra Minerva. Také Mánes po svém návratu z italské metropole klade - podobně jako Hellich - důraz na pultík Panny Marie, tentokrát však s výrazným podnožím v podobě kubického tělesa. ${ }^{135}$

Tuto Mánesovu skicu lze vnímat nejen pouze jako derniéru jeho vlastní tvorby „povzdechnutí nad nenaplněnými uměleckými i osobními ambicemi, ale také za výraz „labutí písně“ vyčerpané nazarénské klasiky, měnící se v této době do expresivních forem pozdně nazarénské náboženské malby a ornamentálního traktovaní tzv. beuronské školy. ${ }^{136}$

130 K pojmu „autorita obrazu“ a jejímu projevu ve výtvarném umění viz Wimböck 2004, s. 9-41.

131 Obliba „božího prostředníka“ archanděla Gabriela se např. projevila v pojmenování pozdějšího proslulého mnichovského malíre Gabriela von Maxe, jako výraz sebeidentifikace jeho otce, pražského sochaře Josefa Maxe s nazarénským hnutím.

132 Srov. např. Jindřich Anger - Miroslav Anger, Josef Mánes. Dopisy, Praha 1998, s. 75.

133 Publikovaná v Hana Volavková, Josef Mánes, malír vzorků a ornamentu, Praha 1981, s. 191, 192, 202.

134 Josef Mánes pracuje nikoli s pojmem „Zvěstování Panně Marii“, nýbrž „Andělské pozdraveni““ („Andelsk Pozravene"). Podobně Mánes plánoval zcela v kontextu nazarénských strategií svou kompozici Albrecht Dürer při přechodu Alp. Metodologické srov. Lehr (pozn. 12), s. 86-88. Hravá, výtvarně-osobní sebereflexe se u Mánesa objevuje také např. na jeho „sekularizované“ mariánské kresbě, Madoně s lorňonem z první poloviny 50. let 19 . stol.

135 Typus čtenářského pultíku používaný např. v italských klášterech v 15. a 16. století. Srov. např. s dílem řezbáře Fra Raffaele da Brescia v Museo Cristiano v severoitalské Brescii Alessandro Nova, Girolamo Romanino, Torino 1994, s. 263-264.

136 Srov. s dodnes nepřekonanou studií: Harald Siebenmorgen, Die Anfänge der „Beuroner Kunstschule“ Peter Lenz und Jakob Wüger 1850-1875. Ein Beitrag zur Genese der Formabstraktion in der Moderne, Sigmaringen 1983, s. 71-73. 


\section{LITERATURA}

Jindřich Anger - Miroslav Anger, Josef Mánes. Dopisy, Praha 1998.

Daniel Arasse, L'Annonciation italienne. Une historie de perspective, Paris 1999.

Diego Arenhoevel - Alfons Deissler - Anton Vögtle (edd.), Die Bibel. Die Heilige Schrift des Alten und Neuen Bundes. Deutsche Ausgabe mit den Erläuterungen der Jerusalemer Bibel, Freiburg - Basel - Wien 1969.

Oskar Bätschmann, Das Historienbild als „tableau“ des Konflikts: Jacques-Louis Davids „Brutus“ von 1789, Wiener Jahrbuch für Kunstgeschichte XXXIX, 1986, s. 156-159.

Franz Binder (ed.), [Margaret Howitt], Friedrich Overbeck. Sein Leben und Schaffen. Nach seinen Briefen und andern Documenten des handschriftlichen Nachlasses geschildert von Margaret Howitt. Erster Band: 1789-1833, Freiburg im Breisgau 1886.

Franz Binder (ed.), [Margaret Howitt], Friedrich Overbeck. Sein Leben und Schaffen. Nach seinen Briefen und andern Documenten des handschriftlichen Nachlasses geschildert von Margaret Howitt. Zweiter Band: 1833-1869, Freiburg im Breisgau 1886.

Friedrich von Boetticher, Malerwerke des neunzehnten Jahrhunderts II/I, Hofheim 1979.

Daniela Bohde, „Le tinte delle carni“. Zur Begrifflichkeit für Haut und Fleisch in italienischen Kunsttraktaten des 15. bis 17. Jahrhunderts, in: Daniela Bohde - Mechthild Fend (edd.), Weder Haut noch Fleisch. Das Inkarnat in der Kunstgeschichte, Berlin 2007, s. 53 ad.

Helmut Börsch-Supan, Deutsche Romantiker zwischen 1800 und 1850, München - Gütersloh - Wien 1972.

Helmut Börsch-Supan, Die Deutsche Malerei von Anton Graff bis Hans von Marées. 1760-1870, München 1988.

Clemens Brentano, Ausgewählte Werke. Bd. II, München 1963.

Karl Brömel, Ludwig Tiecks Kunstanschauungen im „Sternbald“ (disertační práce), Universität Leipzig, Leipzig 1928.

Francesco Buranelli, L'appartamento Borgia in Vaticano, in: Vittoria Garibaldi - Francesco Federico Mancini (edd.), Pintoricchio (katalog výstavy), Galleria Nazionale dell’Umbria 2008, s. 69 ad.

Werner Busch, Die notwendige Arabeske, Berlin 1985.

Werner Busch, Das sentimentalische Bild. Die Krise der Kunst im 18. Jahrhundert und die Geburt der Moderne, München 1993.

Frank Büttner, Der Streit um die „Neudeutsche religiös-patriotische Kunst“, Aurora. Jahrbuch der Eichendorff-Gesellschaft XLIII, 1983, s. 55-76.

Frank Büttner, Peter Cornelius. Fresken und Freskenprojekte. Band 1, Wiesbaden 1980.

Frank Büttner, Aufstieg und Fall der Geschichtsmalerei. Ein Überblick über die Entwicklung von Gattungsgeschichte und Gattungstheorie in Deutschland vom späten 18. bis zum frühen 20. Jahrhundert, in: Ulrich Baumgärtner - Monika Fenn (edd.), Geschichte zwischen Kunst und Politik, Münchner Geschichtsdidaktisches Kolloquium, Heft 4, München 2002, s. 36 ad.

F.[rank] O.[laf] Büttner, Imitatio Pietatis. Motive der christlichen Ikonographie als Modelle zur Verähnlichung, Berlin 1983.

Anna Cavallaro, Antoniazzo Romano e gli Antoniazzeschi. Una generazione di pittori nella Roma del Quattrocento, Udine 1992.

Anna Cavallaro, Antoniazzo Romano, in: Maria Grazia Bernardini - Marco Bussagli (edd.), Il'400 a Roma. La rinascita delle arti da Donatello a Perugino (katalog výstavy), Museo del Corso, Roma 2008, s. 169-173.

Gert Duwe, Der Wandel in der Darstellung der Verkündigung an Maria vom Trecento zum Quattrocento, Frankfurt am Main - Bern - New York - Paris 1988.

Gert Duwe, Die Verkündigung an Maria in der niederländischen Malerei des 15. und 16. Jahrhunderts, Frankfurt am Main - Berlin - Bern - New York - Paris - Wien 1994.

Alois Dyk, Oltář sv. Lukáše v Týnském chrámu v Praze. Z listin a pozůstalosti Jos. Vojtěcha Hellicha, nepublikováno, 1960 (Památník národního písemnictví, fond Josef Vojtěch Hellich, kartón 12)

Paul Eich, Über das Verhältnis der Nazarener zum Mittelalter, in: Klaus Gallwitz (ed.), Die Nazarener (katalog výstavy), Städtische Galerie im Städelschen Kunstinstitut Frankfurt am Main 1977, s. 27-40. Herbert von Einem, Deutsche Malerei des Klassizismus und der Romantik. 1760-1840, München 1978. 
Herbert von Einem, Die Ausmalung der Festsäle durch Peter Cornelius, in: Klaus Vierneisel - Gottlieb Leinz (edd.), Glyptothek München 1830-1980 (katalog výstavy), Glypthotek München 1980, s. 214-233.

Barbara Eschenburg, Vom Spätmittelalter bis zur Neuen Sachlichkeit. Die Gemälde im Lenbachhaus München, München - Berlin 2009.

Rachel Esner, Auf der Suche nach verlorener Zeit. Überlegungen zu Overbeck und Ingres, in: Andreas Blühm - Gerhard Gerkens (edd.), Johann Friedrich Overbeck. 1789-1869. Zweihundertsten Wiederkehr seines Geburtstages (katalog výstavy), Museum für Kunst und Kulturgeschichte der Hansestadt Lübeck - Behnhaus 1989, s. 54-62.

Sabine Fastert, Die Entdeckung des Mittelalters, München - Berlin 2000.

Corrado Fratini - Giulio Proietti Bocchini, Gli affreschi della capppella Baglioni nella collegiata di Santa Maria Maggiore a Spello, in: Vittoria Garibaldi - Francesco Federico Mancini (edd.), Pintoricchio (katalog výstavy), Galleria Nazionale dell’Umbria, Perugia 2008, s. 113 ad.

Jochen Fried, Friedrich Ludwig Zacharias Werner, in: Walther Killy (ed.), Literaturlexikon. Bd. 12, Gütersloh - München 1992, s. 258-260.

Hannelore Gärtner, Patriotismus und Gotikrezeption der deutschen Frühromantik, in: Peter Betthausen (ed.), Studien zur deutschen Kunst und Architektur um 1800, Dresden 1981, s. 34-52.

Hans Geller, Ernste Künstler, fröhliche Menschen. Zeichnungen und Aufzeichnungen deutscher Künstler in Rom zu Beginn des 19. Jahrhunderts. Joseph Führich und seine Freunde, München 1947.

Gerhard Gerkens, Bildnis des Malers Franz Pforr, in: Andreas Blühm - Gerhard Gerkens (ed.), Johann Friedrich Overbeck. 1789-1869. Zwei zweihundertsten Wiederkehr seines Geburtstages (katalog výstavy), Museum für Kunst und Kulturgeschichte der Hansestadt Lübeck, Lübeck - Behnhaus 1989, s. 114 ad.

Ernst H. Gombrich - Ernst Kris - Otto Kurz, Die Legende vom Künstler, Frankfurt am Main 1980.

Maria Elisabeth Gössmann, Die Verkündigung an Maria im dogmatischen Verständnis des Mittelalters, München 1957.

Cordula Grewe, Objektivierte Subjektivität: Identitätsfindung und religiöse Kommunikation im nazarenischen Kunstwerk, in: Max Hollein - Christa Steinle (edd.), Religion Macht Kunst. Die Nazarener (katalog výstavy), Schirn Kunsthalle Frankfurt am Main 2005, s. 79-90.

Cordula Grewe, Re-enchantment as Artistic Practise: Strategies of Emulation in German Romantic Art and Theory, New German critique XCIV, 2005, s. 58 ad.

Ludwig Grote, Joseph Sutter und der nazarenische Gedanke, München 1972.

Rose-Maria Gropp, Wiederkehr eines Verschollenen. Vorschau: Kunst und Kunstgewerbe bei Van Ham in Köln, Frankfurter Allgemeine Zeitung, 12. November 2011, př́loha Kunstmarkt.

Joachim Großmann, Historienmalerei im 19. Jahrhundert - Entstehungsbedingungen und Rezeption, Kritische Berichte. Zeitschrift für Kunst und Kulturwissenschaften XX, 1992, č. 2, s. 24-35.

Teresa Grzybkowska, Overbecka interpretacja Sposalizio Rafaela, in: Marta i Wojciech Boberscy Mieczysłav Morka - Hanna Samsonowicz (edd.), Między Padwa a Zamościem. Studia z historii sztuki $i$ kultury nowożytnej ofiarowane profesorowi Jerzemu Kowalczykowi, Warszawa 1993, s. 372-373.

Herwig Guratzsch (ed.), Julius Schnorr von Carolsfeld 1794-1872 (katatog výstavy), Museum der bildenden Künste Leipzig 1994.

Paul Guyer, Exemplary Originality: Genius, Universality, and Individuality, in: Berys Gaut - Paisley Livingston (edd.), The Creation of Art. New Essays in Philosophical Aesthetics, Cambridge 2003, s. $116-118$.

Max Haase, Ein unvollendetes Aquarell Franz Pforrs, Städel-Jahrbuch, Neue Folge - Band II, 1969, s. 303-304.

Arnold Hauser, Soziologie der Kunst, München 1974.

Brigitte Heise, Johann Friedrich Overbeck. Das künstlerische Werk und seine literarischen und autobiographischen Quellen, Köln - Weimar - Wien 1999.

Edward B. Henning, Patronage and Style in the Arts: A Suggestion Concerning Their Relations, in: Milton C. Albrecht - James H. Barnett - Mason Griff (edd.), The Sociology of Art and Literature, New York 1976, s. 359-361.

Mareike Henning, Mit freier Hand. Deutsche Zeichnungen vom Barock bis zur Romantik aus dem Städelschen Kunstinstitut (katalog výstavy), Städelsches Kunstinstitut und Städtische Galerie, Frankfurt am Main 2003. 
Tom Henry, I committenti di Raffaello a Città di Castello (Raphael's patrons in Città di Castello), in: Tom Henry - Francesco Federico Mancini (edd.), Gli esordi di Raffaello tra Urbina, Città di Castello e Perugia (katalog výstavy), Palazzo Vitelli alla Cannoniera, Pinacoteca Comunale, Città di Castello e Perugia, Castello e Perugia 2006, s. 49-54.

Berthold Hinz, Säkularisation als verwerteter „Bildersturm“. Zum Prozeß der Aneignung der Kunst durch die Bürgerliche Gesellschaft, in: Martin Warnke (ed.), Bildersturm. Die Zerstörung des Kunstwerks, München 1973, s. 108-120, 170-176.

Werner Hofmann, Das Irdische Paradies. Motive und Ideen des 19. Jahrhunderts, München 1974.

Anita Izcovich, Le corps précieux. Essai sur la peinture maniériste, Paris 2003.

Georg Jäger, Das Gattungsproblem in der Ästhetik und Poetik von 1780 bis 1850, in: Jost Hermand Manfred Windfuhr (edd.), Zur Literatur der Restaurationsepoche 1815-1848, Stuttgart 1970, s. 371404.

Manfred Jauslin, Die gescheiterte Kulturrevolution. Perspektiven religiös-romantischer Kunstbewegung vor der Folie der Avantgarde (disertační práce), Universität Basel 1988.

Jens Christian Jensen, Gedenkblatt für den Maler Franz Pforr, den Freund Friedrich Overbeck, in: Paul Brockhaus (ed.), Der Wagen 1963. Ein Lübeckisches Jahrbuch, Lübeck 1963, s. 87 ad.

Jens Christian Jensen, Sulamith und Maria, in: Bruno Bushart - Matthias Eberle - Jens Christian Jensen (edd.), Museum Georg Schäfer, Schweinfurt 2000, s. 174-176.

Roland Kanz, Die Einheit des Charakters. Die Seelenhafte, Symbolische und Charakteristische in dem Porträt - Ästhetik der Romantik, Zeitschrift für Ästhetik und allgemeine Kunstwissenschaft XLIII, 1998, č. 2, s. 229-243;

Claude Keisch (ed.), Classici e romantici tedeschi in Italia (katalog výstavy), Ala Napoleonica, Venezia 1977.

Harald Keller, Goethes Hymnus auf das Straßburger Münster und die Wiederentdeckung der Gotik im 18. Jahrhundert. 1772/1972, München 1972.

Paul Wilhelm von Keppler, Aus Kunst und Leben, Freiburg im Breisgau 1911.

Eckart Kleßmann, Die deutsche Romantik, Köln am Rhein 1979.

Raymond Klibansky - Erwin Panofsky - Fritzl Saxl, Saturn und Melancholie, Frankfurt am Main 1990.

Karl Koetschau, Einige Kartons und Bilder von Ernst Deger, Düsseldorf cca 1925.

Margaret L. Koster, Hugo van der Goes and the procedures of art and salvation, Turnhout 2008.

Michael Krapf - Hans Bisanz, Johann Evangelist Scheffer von Leonhardshoff 1795-1822. Ein Mitglied des Lukasbundes aus Wien (katalog výstavy), Obere Belvedere - Österreichische Galerie, Historisches Museum der Stadt Wien, Wien 1977.

Michael Krapf, Zu den Voraussetzungen der Entstehung des Lukasbundes in Wien, in: Klaus Gallwitz (ed.), Die Nazarener in Rom. Ein deutscher Künstlerbund der Romantik (katalog výstavy), Galleria Nazionale d'Arte Moderna, Roma 1981, s. 27-33.

Klaus Lankheit, Freundschaftsbild der Romantik, Heidelberg 1952.

Fritz Herbert Lehr, Die Blütezeit romantischer Bildkunst. Franz Pforr der Meister des Lukasbundes, Marburg an der Lahn 1924.

Renate Liebenwein-Krämer, Säkularisierung und Sakralisierung. Studien zum Bedeutungswandel christlicher Bildformen in der Kunst des 19. Jahrhunderts (disertační práce), Johann Wolfgang Goethe Universität zu Frankfurt am Main 1977.

Julia Liebrich, Die Verkündigung an Maria. Die Ikonographie der italienischen Darstellungen von den Anfängen bis 1500, Köln - Weimar - Wien 1997.

Alfred Lichtwark, Julius Oldach, Hamburg 1899.

Kurt Löcher, Zu Franz Pforrs „Einzug Kaiser Rudolfs von Habsburg in Basel“ - Vom nutzen Wiener Studienjahre, in: Bruno Klein - Harald Wolter von dem Knesebeck (edd.), Nobilis arte manus. Festschrift zum 70. Geburtstag von Antje Middeldorf Kosegarten, Dresden - Kassel 2002, s. 428-440.

Sven Lüken, Die Verkündigung an Maria im 15. und frühen 16. Jahrhundert, Göttingen 2000.

Louisa C. Matthew, Method and meaning in an altarpiece by Lorenzo Lotto, Renaissance Studies VIII, 1994, č. 2, June, s. 165.

Steffan Matter - Maria-Christina Boerner, ...kann ich vielleicht nur dichtend mahlen? Franz Pforrs Fragment eines Künstlerromans und das Verhältnis von Poesie und Malerei bei den Nazarenern, Köln Weimar - Wien 2007. 
Sigrid Metken, Verkündigung und Heimsuchung, in: Klaus Gallwitz (ed.), Die Nazarener in Rom. Ein deutscher Künstlerbund der Romantik (katalog výstavy), Galleria Nazionale d’Arte Moderna, Roma 1981.

Heinz Meyer, Metaphern des Psaltertextes in den Illustrationen des Stuttgarter Bilderpsalters, in: Christel Meier - Uwe Ruberg (edd.), Text und Bild. Aspekte des Zusammenwirkens zweier Künste in Mittelalter und früher Neuzeit, Wiesbaden 1980, s. 198 ad.

Norbert Miller, Mutmaßungen über lebende Bilder. Attitüde und „tableau vivant“ als Anschauungsform des 19. Jahrhunderts, in: Helga de la Motte - Haber (ed.), Das Triviale in Literatur, Musik und Bildender Kunst, Frankfurt am Main 1972, s. 123 ad.

Pia Müller-Tamm, Nazarenische Zeichenkunst (katalog výstavy), Städtische Kunsthalle Mannheim, Mannheim 1993.

Lothar Müller (ed.), [August Wilhelm Schlegel], Die Gemählde. Gespräch, Dresden 1996.

Hans Joachim Neidhardt, Deutsche Malerei des 19. Jahrhunderts, Leipzig 1990.

Mirjam Neumeister, Das Nachtstück mit Kunstlicht in der niederländischen Malerei und Graphik des 16. und 17. Jahrhunderts. Ikonographische und koloristische Aspekte (disertační práce), Universität Bonn 1999.

Alfred Neumeyer, Die Erweckung der Gotik in der deutschen Kunst des späten 18. Jahrhunderts. Ein Beitrag zur Vorgeschichte der Romantik (disertační práce), Friedrich Wilhelms Universität zu Berlin 1928.

Helmut Nickel, The Bride and the Cat: A Possible Source for Overbeck's Freundschaftsbild of Franz Pforr, Metropolitan Museum Journal XXVII, 1992 (Essays in Memory of Guy C. Bauman), s. 183-187.

Gisela Noehles-Doerk, Antoniazzo Romano. Studien zur Quattocentomalerei in Rom (disertační práce), Westfälischen Wilhelms Universität zu Münster 1973.

Thomas Noll, Religiöse Verehrung und ästhetischer Genuß. Zur Wahrnehmung von Bildern im späten Mittelalter, in: Sabine Arend - Daniel Berger - Carola Brückner et al. (edd.), Vielfalt und Aktualität des Mittelalters. Festschrift für Wolfgang Petke zum 65. Geburtstag, Bielefeld 2006, s. 403-424.

Alessandro Nova, Girolamo Romanino, Torino 1994.

Novalis (Friedrich von Hardenberg), Hymny $k$ poctě noci, Praha 2000.

Jacqueline Olson Padgett, Ekphrasis, Lorenzo Lotto囚s Annunciation, and the hermeneutics of suspicion, Religion and the Arts 10, 2006, č. 2, s. 191-201.

Erwin Panofsky, Idea. Ein Beitrag zur Begriffgeschichte der älteren Kunsttheorie, Berlin 1960.

Antonio Paolucci, Antoniazzo Romano. Catalogo completo, Firenze 1992.

Helène Papastavrou, Recherche iconographique dans l'art Byzantin et occidental du XIe au XVe siècle L'annonciation, Venise 2007.

J.[ohann] D. [avid] Passavant, Rafael von Urbino und sein Vater Giovanni Santi von J.D. Passavant. In zwei Theilen mit vierzehn Abbildungen. Erster Theil, Leipzig 1839.

Claudio Poppi (ed.), Sventurati amanti. Il mito di Paolo e Francesca nell' 800 (katalog výstavy), Museo della città Rimini 1994.

Rudolf Preimesberger, Zu Jan van Eycks Diptychon der Sammlung Thyssen-Bornemisza, Zeitschrift für Kunstgeschichte LIV, 1991, Heft 4, s. 459-489.

Rudolf Preimesberger, Einleitung, in: Rudolf Preimesberger - Hannah Baader - Nicola Suthor (edd.), Porträt, Berlin 1999, s. 50 ad.

Cornelia Reiter, Suche nach dem Unendlichen. Aquarelle und Zeichnungen der deutschen und österreichischen Romantik aus dem Kupferstichkabinett der Akademie der bildenden Künste Wien, München - London - New York 2001.

Stefanie Renner, Die Darstellung der Verkündigung an Maria in der florentinischen Malerei. Von Andrea Orcagna (1346) bis Lorenzo Monaco (1425), Bonn 1996.

Nicole Reynaud, Très Petites Heures d'Anne de Bretagne, in: François Avril - Nicole Reynaud (edd.), Les manuscrits à peintures en France 1440-1520 (katalog výstavy), Bibliothèque Nationale, Paris 1993, s. 266 ad.

Nicole Reynaud, Heures à l'usage de Rome, in: François Avril - Nicole Reynaud (edd.), Les manuscrits à peintures en France 1440-1520 (katalog výstavy), Bibliothèque Nationale, Paris 1993, s. 268 ad.

Annamaria Rossi, Benedetto Bonfigli, Annunciazione e san Luca, in: Vittoria Garibaldi (ed.), Un pittore e la sua città. Benedetto Bonfigli e Perugia (katalog výstavy), Galleria Nazionale dell'Umbria, Perugia 1996. 
Jan Řezáč, Transformace forem a témat nazarénského malǐrství v Čechách na př́ikladu oltár̆ního obrazu Josefa Vojtěcha Hellicha (magisterská práce), Univerzita Karlova Praha 2009.

Jan Řezáč, Evropský kontext k ztvárnění figury v českém malírství druhé třetiny 19. století. Ideové a formální zázemí tvorby Josefa Mánesa (disertační práce), Univerzita Karlova Praha 2015.

Adelheid von Saldern, Rauminszenierungen. Bürgerliche Selbstrepräsentationen im Zeitenumbruch (1880-1930), in: Werner Plumpe - Jörg Lesczenski (edd.), Bürgertum und Bürgelichlichkeit zwischen Kaiserreich und Nationalsozialismus, Mainz 2009, s. 39-55.

Pietro Scarpellini - Maria Rita Silvestrelli, Pintoricchio, Milano 2004.

Hans Sedlmayr, Kunst und Wahrheit. Zur Theorie und Methode der Kunstgeschichte, Hamburg 1958.

Hans Sedlmayr, Verlust der Mitte. Die bildende Kunst des 19. und 20. Jahrhunderts als Symptom und Symbol der Zeit, Salzburg 1965.

Luigi Sensi - Bartolomeo Pinelli, Riproduzione grafica della capella Baglioni, in: Vittoria Garibaldi Francesco Federico Mancini (edd.), Pintoricchio (katalog výstavy), Galleria Nazionale dell'Umbria, Perugia 2008, s. 290 ad.

Karl Schade, Andachtsbild. Die Geschichte eines kunsthistorischen Begriffs, Weimar 1996.

Walther Scheidig, Franz Horny. 1798 Weimar - Olevano 1824, Berlin 1954.

Herbert Schindler, Nazarener. Romantischer Geist und christliche Kunst im 19. Jahrhundert, Regensburg 1982.

Paul Ferdinand Schmidt, Die Lukasbrüder. Der Overbecksche Kreis und seine Erneuerung der religiösen Malerei, Berlin 1924.

U.[rsel] Schönrock - H.[ans]-W.[erner] Grohn, Skulpturenabteilung, Gemäldegalerie. Staatliche Museen zu Berlin, Berlin 1953.

Christian Scholl, Romantische Malerei als neue Sinnbildkunst. Studien zur Bedeutungsgebung bei Philipp Otto Runge, Caspar David Friedrich und den Nazarenern, München - Berlin 2007.

Klaus Schreiner, Maria. Jungfrau, Mutter, Herrscherin, München - Wien 1994.

Elisabeth Schröter, Raffael-Kult und Raffael-Forschung. Johann David Passavant und seine RaffaelMonographie im Kontext der Kunst und Kunstgeschichte seiner Zeit, Römisches Jahrbuch der Bibliotheca Hertziana XXVI, 1990, s. 309-318.

Elisabeth Schröter, Raffael und der Heilige Lucas. August Wilhelm Schlegels „Legende vom Heiligen Lucas“: Wirkung und Quellen - Kunstgeschichte und Poesie im Dialog, Zeitschrift für Kunstgeschichte LXII, 1999, Heft 3, s. 418-431.

Dora Schumann, Die Darstellungen der Verkündigung in der italienischen Kunst der Renaissance (disertační práce), Universität Heidelberg 1910.

Harald Siebenmorgen, Die Anfänge der „Beuroner Kunstschule“ Peter Lenz und Jakob Wüger 1850-1875. Ein Beitrag zur Genese der Formabstraktion in der Moderne, Sigmaringen 1983.

Hinrich Sieveking, Von Füssli bis Menzel. Aquarelle und Zeichnungen der Goethezeit aus einer Münchner Privatsammlung (katalog výstavy), Kunstsammlungen zu Weimar 1997.

Maurits Smeyers, Boodschap aan Maria. - Navolger van Dirk Bouts, in: Maurits Smeyers (ed.), Dirk Bouts (ca. 1410-1475) een Vlaams primitief te Leuven (katalog výstavy), Sint - Pieterskerk en Predikherenkerk te Leuven 1998, s. 384 ad.

Martin Sonnabend, Franz Pforr in Rom, in: Margret Stuffmann - Werner Busch (edd.), Zeichnen in Rom 1790-1830, Köln am Rhein 2001, s. 48 ad.

Ellen Spickernagel, „Das Innerste erschüttern und bewegen“ Zur religiösen Tafelmalerei der Nazarener, in: Klaus Gallwitz (ed.), Die Nazarener (katalog výstavy), Städtische Galerie im Städelschen Kunstinstitut Frankfurt am Main 1977, s. 117 ad.

Heidrun Stein-Kecks, „Santa (sacra) Conversazione“ Viele Bilder, ein Begriff und keine Definition, in: Karl Möseneder - Gosbert Schüssler (edd.), „Bedeutung in den Bildern“ Festschrift für Jörg Traeger zum 60. Geburtstag, Regensburg 2002, s. 413-442.

Claudio Strinati, Linee di tendenza nella pittura a Roma del Quattrocento, in: Maria Grazia Bernardini Marco Bussagli (edd.), Il'400 a Roma. La rinascita delle arti da Donatello a Perugino (katalog výstavy), Museo del Corso, Roma 2008, s. 38 ad.

Norbert Suhr, Philipp Veit (1793-1877). Leben und Werk eines Nazareners. Monographie und Werkverzeichnis, Weinheim 1991.

Emil Sulger Gebing, A. W. und F. Schlegel in ihrem Verhältnisse zur bildenden Kunst, Hildesheim 1976. 
Michael Teichmann, Julius Schnorr von Carlolsfeld (1794-1872) und seine Ölgemälde. Monographie und Werkverzeichnis, Frankfurt am Main 2001.

Daniel Ternois - Ettore Camasasca, Tout l'ouvre peint d'Ingres, Paris 1971.

Reinhard Teske, Studien zur Genremalerei im Vormärz (disertační práce), Universität Stuttgart 1976.

Michael Thimann, Der ,glücklichste kleine Freystaat von der Welt"? Friedrich Overbeck und die Nazarener in Rom, in: Ulrich Raulff (ed.), Vom Künstlerstaat. Ästhetische und politische Utopien, München Wien 2006, s. 61-96.

Michael Thimann, Notwendige Arabesken bei den Nazarenern. Zu Friedrich Overbeck, Verkündigung und Heimsuchung (1814/1816), Das Münster LXV, 2012, č. 2, s. 118-125.

Ludwig Tieck, Franz Sternbalds Wanderungen, Stuttgart 1994.

Jörg Traeger, Renaissance und Religion. Die Kunst des Glaubens im Zeitalter Raphaels, München 1997.

Hana Volavková, Josef Mánes, malír vzorki̊ a ornamentu, Praha 1981.

Elmar Vonbank (ed.), Gebhard Flatz 1800-1881 (katalog výstavy), Marktgemeinde Wolfurt, Wolfurt 1982.

Wilhelm Heinrich Wackenroder - Ludwig Tieck, Herzensergießungen eines kunstliebenden Klosterbruders, Stuttgart 1987.

Ulrich Weisstein, Einleitung. Literatur und bildende Kunst: Geschichte, Systematik, Methoden, in: Ulrich Weisstein (ed.), Literatur und bildende Kunst. Ein Handbuch zur Theorie und Praxis eines komparatistischen Grenzgebietes, Berlin 1992, s. 11-31.

[Zacharias Werner], Zacharias Werner's Poetische Werke III, Grimma 1845.

Friedrich Ludwig Zacharias Werner, Ausgewählte Schriften. Poetische Werke. Gedichte bis zum Jahre 1810. Bd. 1, Bern 1970.

Gabriele Wimböck, Die Autorität des Bildes - Perspektiven für eine Geschichte vom Bild in der Frühen Neuzeit, in: Frank Büttner - Gabriele Wimböck (edd.), Das Bild als Autorität. Die normierende Kraft des Bildes, Münster 2004, s. 9 ad.

Friedrich Winkler, Das Werk des Hugo van der Goes, Berlin 1964.

Telse Wolf-Timm, Theodor Rehbenitz 1791-1861. Persönlichkeit und Werk, Kiel 1991.

Hans-Joachim Ziemke, Die Anfänge in Wien und in Rom, in: Klaus Gallwitz (ed.), Die Nazarener (katalog výstavy), Städtische Galerie im Städelschen Kunstinstitut Frankfurt am Main 1977, s. 46 ad.

Hans-Joachim Ziemke, Franz Pforrs Studium Bericht, in: Hildegard Bauereisen - Martin Sonnabend (edd.), Correspondances. Festschrift für Margret Stuffmann zum 24. November 1996, Mainz 1996, s. 142 ad. 


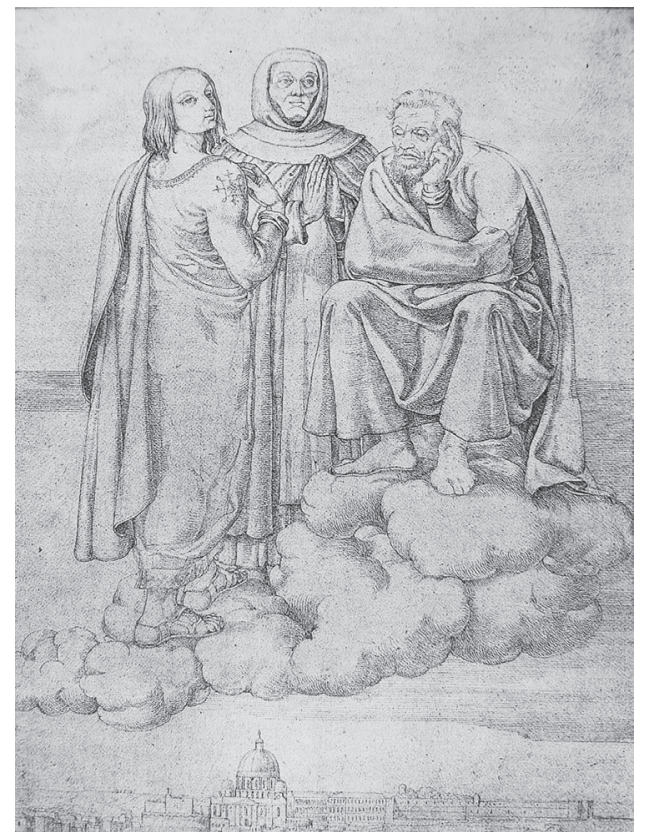

Obrázek 1: Franz Pforr, Raffael, Fra Angelico a Michelangelo, zjevující se na oblaku nad Římem, 1810, tužka, papír, $301 \times 208 \mathrm{~mm}$, neznačeno, Städelsches Kunstinstitut, Frankfurt am Main, inv. č. 6.

Repro: Mitchell Benjamin Frank, German Romantic Painting Redefined. Nazarene tradition and the narratives of Romanticism, Aldershot 2001, s. 90.

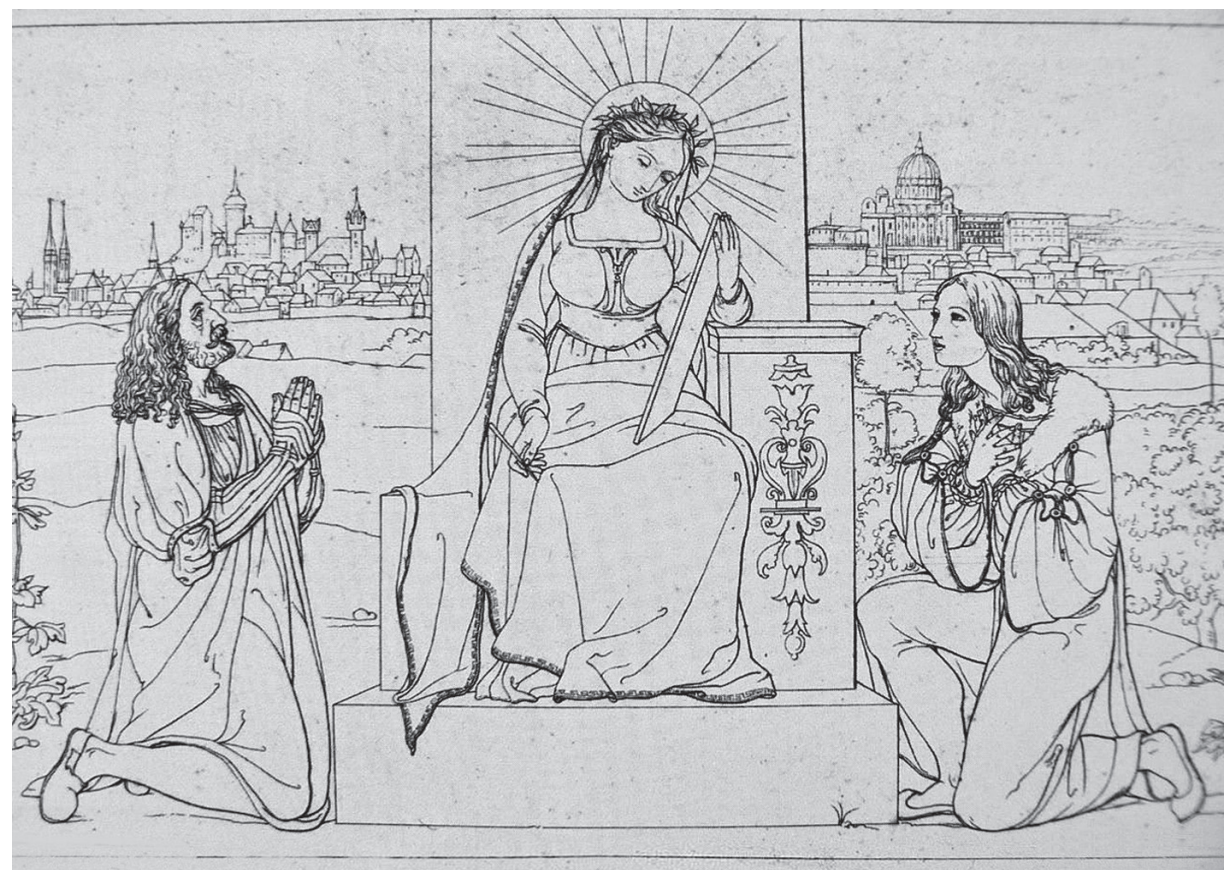

Obrázek 2: Franz Pforr (- Carl Hoff ml.), Albrecht Dürer a Raffael, klečící v adorační modlitbě před personifikovaným trůnícím Uměním, př̀ed 1832, rytina, papír, 137 × $214 \mathrm{~mm}$, neznačeno.

Repro: Max Hollein - Christa Steinle (edd.), Religion Macht Kunst. Die Nazarener (katalog výstavy), Schirn Kunsthalle Frankfurt am Main 2005, s. 60. 

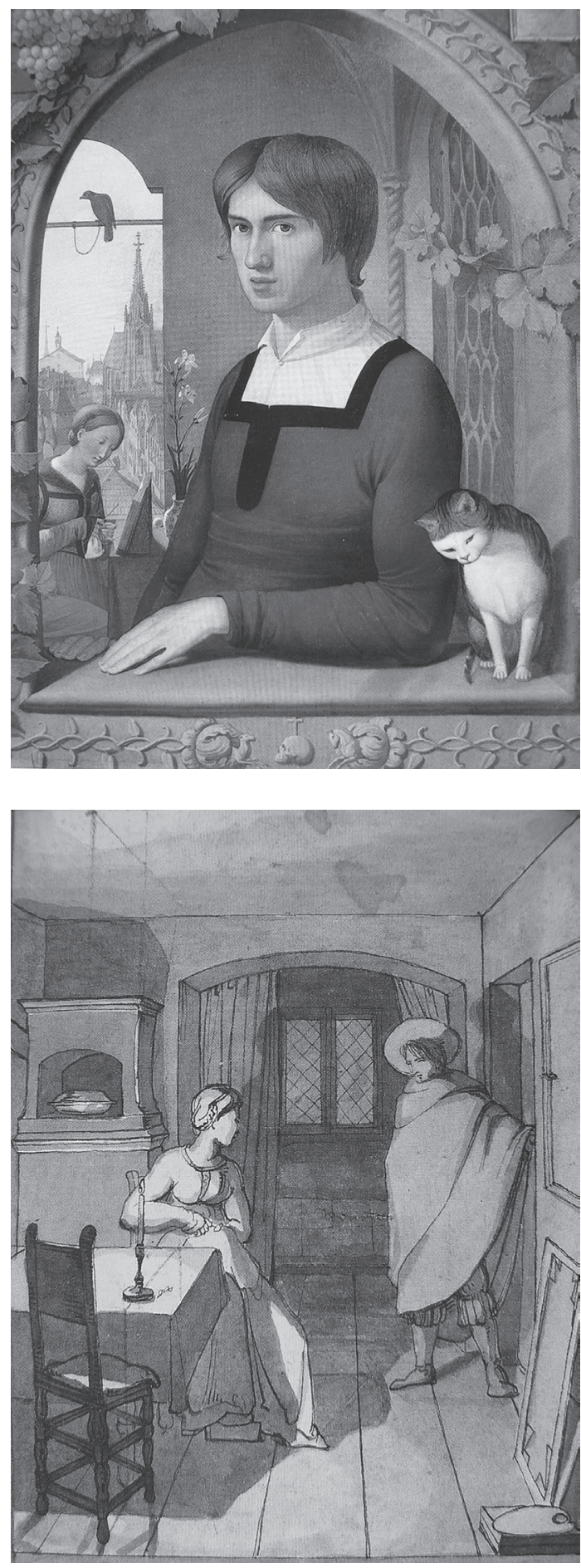

Obrázek 3: Johann Friedrich Overbeck, Portrét Franze Pforra, 1810, olej, plátno, $62 \times 47 \mathrm{~cm}$, neznačeno, Staatliche Museen Preußischer Kulturbesitz, Nationalgalerie, Berlin, inv. č. A II 381, NG 1002.

Repro: Max Hollein - Christa Steinle (edd.), Religion Macht Kunst. Die Nazarener (katalog výstavy), Schirn Kunsthalle Frankfurt am Main 2005, s. 103.

Obrázek 4: Franz Pforr, Noční návrat domů, 1808, tužka, pero, tuš, papír, $156 \times 127 \mathrm{~mm}$, neznačeno, soukromá sbírka Alfred Wingterstein, Mnichov.

Repro: Hinrich Sieveking, Von Füssli bis Menzel. Aquarelle und Zeichnungen der Goethezeit aus einer Münchner Privatsammlung (katalog výstavy), Kunstsammlungen zu Weimar 1997, s. 100. 


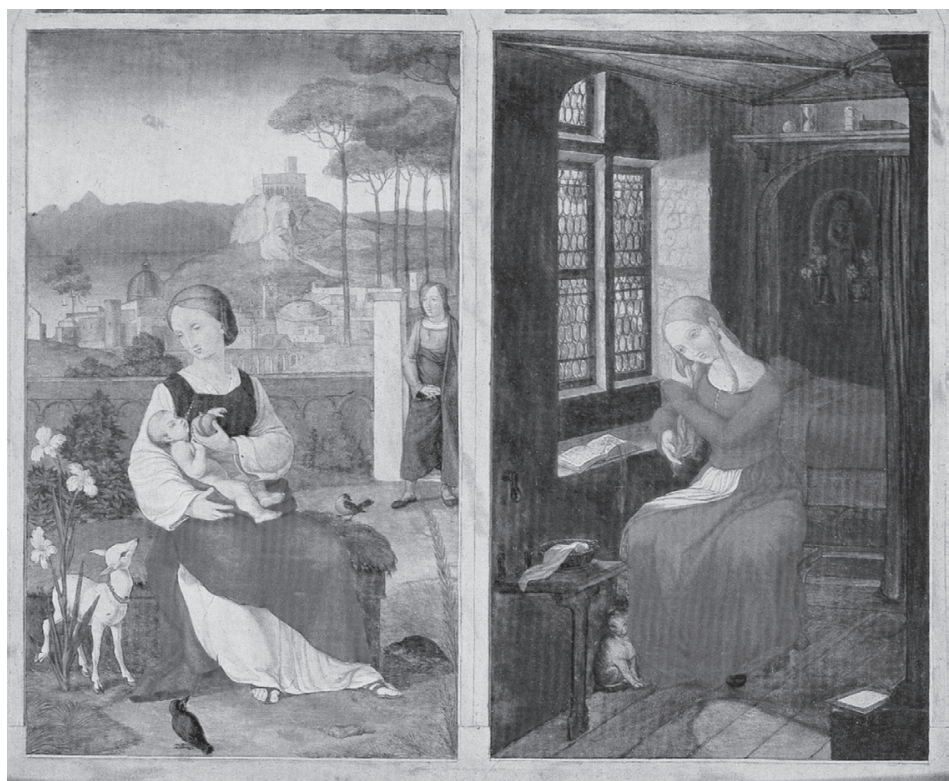

Obrázek 5: Franz Pforr, Sulamith a Marie, 1811 (detail spodní části), olej, dřevěná deska, $34,5 \times 32 \mathrm{~cm}$, neznačeno, Museum Georg Schäfer, Schweinfurt, inv. č. MGS 1183.

Repro: Mitchell Benjamin Frank, German Romantic Painting Redefined. Nazarene tradition and the narratives of Romanticism, Aldershot 2001, s. 17.

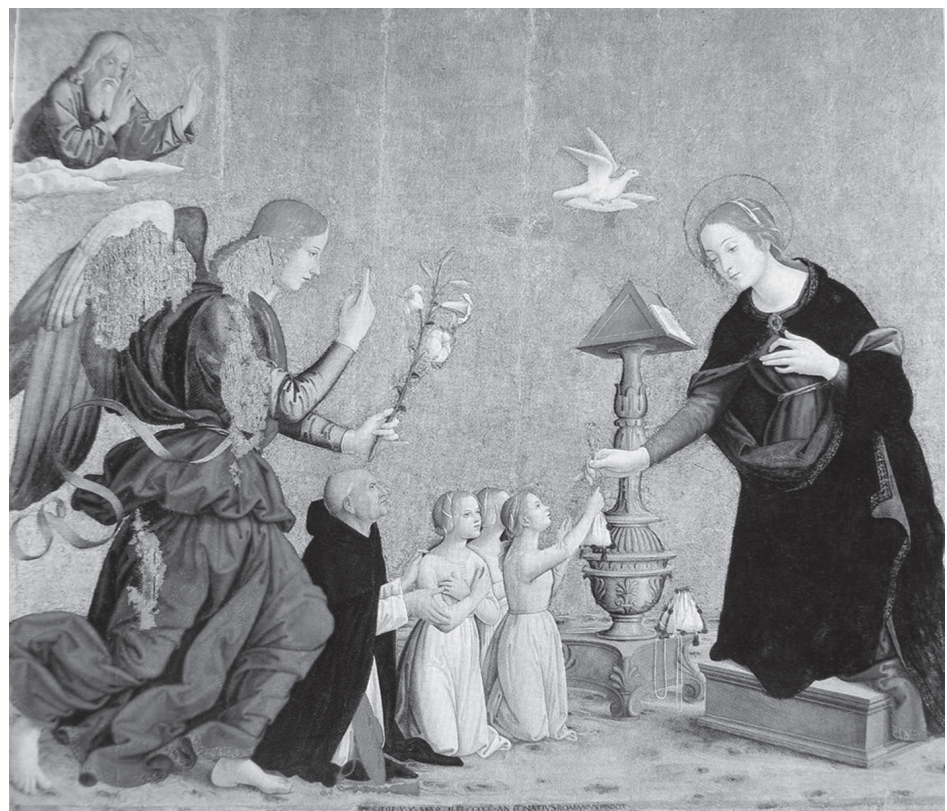

Obrázek 6: Jean Auguste Dominique Ingres, Paolo a Francesca, 1819, olej, plátno, $48 \times 39 \mathrm{~cm}$, signováno a datováno vlevo dole: „INGRES. ROM 1819“, Musée des Beaux Arts, Angers, inv. č. MTC 19. Repro: Daniel Ternois - Ettore Camasasca, Tout l'ouvre peint d'Ingres, Paris 1971, s. 96. 

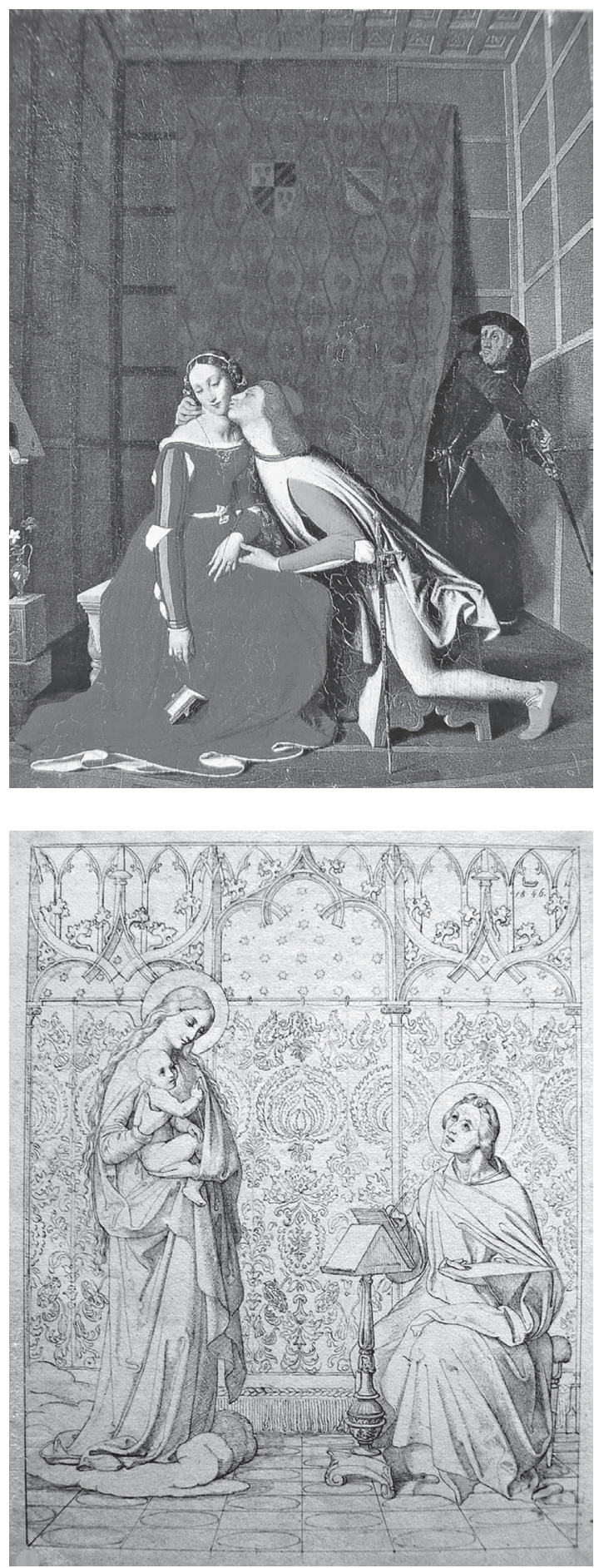

Obrázek 7: Josef Vojtěch Hellich, Sv. Lukáš malující Pannu Marii s Ježiškem, 1846, tužka, pero, černá tuš, papír, $264 \times 212 \mathrm{~mm}$, značeno a datováno v pravém horním rohu: Hellichova značka (antický kahan) a „1846“, Grafická sbírka Národní galerie v Praze, inv. č. K 21773. Repro: Grafická sbírka Národní galerie v Praze, inv. č. K 21773.

Obrázek 8: Antoniazzo Romano, Zvěstování Panně Marii, 1500, tempera, dřevěná deska, $130 \times 185 \mathrm{~cm}$, signováno a datováno: „DIE. XX. MARTII. MCCCCC.ANTONATIUS ROMANUS PINXIT", Santa Maria sopra Minerva, capella dell'Annunziata, Rím.

Repro: Antonio Paolucci, Antoniazzo Romano. Catalogo completo, Firenze 1992, s. 146. 


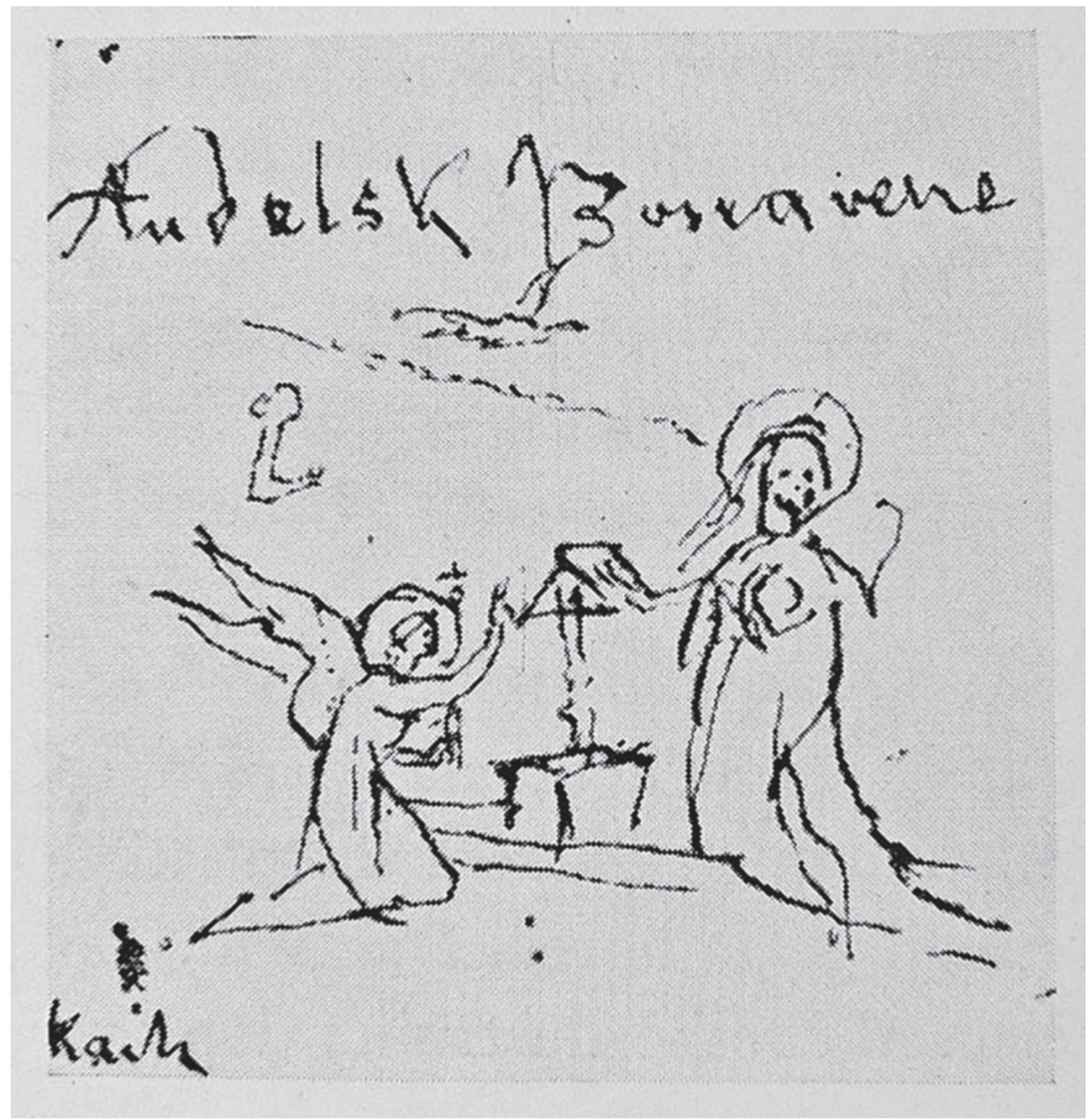

Obrázek 9: Josef Mánes, Zvěstování Panně Marii, 1871, pero, papír.

Repro: Hana Volavková, Josef Mánes, malír vzorků a ornamentu, Praha 1981, s. 192. 